\title{
U POTRAZI ZA ZNAČENJEM STANDARDA EFEKTIVNE KONTROLE U MIROVNIM OPERACIJAMA POD OKRILJEM UN-a
}

Sažetak: $\quad$ Predmet istraživanja analiza je rada Komisije za međunarodno pravo na kodifikaciji odgovornosti međunarodnih organizacija za međunarodno protupravne čine koji je 2011. godine rezultirao usvajanjem Nacrta članaka o odgovornosti međunarodnih organizacija. U središtu analize je odredba čl. 7. Nacrta koja propisuje pretpostavke za pripisivost ponašanja u situacijama kad države ustupaju svoje organe međunarodnim organizacijama radi sudjelovanja u mirovnim operacijama. Kroz analizu relevantnih odluka Europskog suda za ljudska prava $i$ nekih državnih sudova (Nizozemske, Belgije i Ujedinjene Kraljevine) ukazuje se na ključne probleme s kojima su se spomenuti sudovi susretali pri odlučivanju o pripisivosti povreda medunarodnog prava počinjenih u mirovnim operacijama - nedovoljnu jasnoću u formulaciji odredbe o pripisivosti takvih ponašanja, različito tumačenje pojma stavljanja na raspolaganje organa države nekoj međunarodnoj organizaciji, nedefiniranost sadržaja standarda efektivne kontrole koji je, sukladno Nacrtu, propisan kao kriteriji utvrdivanja pripisivosti $i$, posljedično, arbitrarno odredivanje mjerodavnog standarda kontrole. Autorica upozorava da neujednačena praksa i nabrojane manjkavosti Nacrta članaka o odgovornosti medunarodnih organizacija dovode do pravne nesigurnosti $i$ umanjuju mogućnosti žrtava protupravnih čina da dobiju adekvatnu pravnu zaštitu. Zaključno se na temelju provedene analize autorica zalaže za primjenu standarda efektivne kontrole kao dosad već priznatog standarda u kontekstu pripisivosti, izlažu se ključni elementi sadržaja i značenje tog standarda, predlažu smjernice za njegovu ispravnu primjenu i ukazuje na važnost istovremene dvostruke (višestruke) pripisivosti državama i međunarodnim organizacijama.

Ključne riječi: $\quad$ odgovornost međunarodnih organizacija, mirovne operacije Ujedinjenih naroda, standard efektivne kontrole, dvostruka (višestruka) pripisivost ponašanja 


\section{UVOD}

Za razliku od pravila o odgovornosti država za međunarodno protupravne čine, koja je Komisija za međunarodno pravo nakon višedesetljetnog rada kodificirala u Nacrtu članaka o odgovornosti država za međunarodno protupravne čine 2001. godine ${ }^{1}$ (u daljnjem tekstu: Nacrt 2001) i čija je običajnopravna priroda potvrđena u praksi Međunarodnog suda, ${ }^{2}$ pravni okvir koji regulira međunarodnopravnu odgovornost međunarodnih organizacija nije ni približno tako razvijen. Naime, iako je Komisija za međunarodno pravo, nastavljajući rad na kodifikaciji i progresivnom razvoju prava o međunarodnoj odgovornosti desetljeće kasnije izradila i Nacrt članaka o odgovornosti međunarodnih organizacija ${ }^{3}$ (u daljnjem tekstu: Nacrt 2011), oni zbog nekoliko razloga u mnogim aspektima ne odražavaju postojeće međunarodno običajno pravo o odgovornosti međunarodnih organizacija, nego se u značajnom dijelu smatraju progresivnim razvojem međunarodnog prava. ${ }^{4}$

Jedna od glavnih teškoća s kojima se Komisija za međunarodno pravo susretala u formuliranju pravila o odgovornosti međunarodnih organizacija bila je ograničenost dotad postojeće prakse u pogledu utvrđivanja odgovornosti međunarodnih organizacija za međunarodno protupravne čine. ${ }^{5}$ Osim toga, za razliku od država koje su u mnogo većoj mjeri izložene pozivanju na odgovornost pred nacionalnim ili međunarodnim sudovima, vrlo su rijetki slučajevi u kojima međunarodna tijela ili sudovi uopće raspravljaju o zahtjevima za utvrđivanje odgovornosti međunarodnih organizacija. One, naime, tradicionalno uživaju imunitet od jurisdikcije pred domaćim sudovima država. ${ }^{6}$ Stoga je Komisija za međunarodno pravo naglasila da postojeća pravila o odgovornosti međunarodnih organizacija, odnosno Nacrt članaka iz 2011. godine, nemaju autoritet usporediv s odredbama o odgovornosti država te da će pravna snaga članaka o odgovornosti međunarodnih organizacija ovisiti o njihovu prihvaćanju od strane onih na koje se prvenstveno odnosi. ${ }^{7}$

Razlike u konceptu i značaju između Nacrta 2001 i Nacrta 2011 osobito su uočljive u pojedinim odredbama o pripisivosti ponašanja međunarodnoj organizaciji (odredbe čl. 6. do čl. 9. Nacrta 2011). U ovom radu fokusirat ćemo se na odredbu čl. 7. tog Nacrta koja je u teoriji i praksi izazvala nemalo kritika zbog svoje nedorečenosti i očite nemogućnosti jedinstvene

1 Draft Articles on Responsibility of States for Internationally Wrongful Acts, with Commentaries, 2001, Report of the International Law Commission on the Work of Its Fifty-third Session (A/56/10), YILC (2001), sv. II, Part Two.

2 Primjerice, u presudama: Case Concerning Application of the Convention on the Prevention and Punishment of the Crime of Genocide (Bosnia and Herzegovina v. Serbia and Montenegro), Judgement, ICJ Reports (2007), str. 202., para. 385., str. 203., para. 388., str. 207., para. 398., str. 209., para. 401., str. 210., para. 406., str. 217., para. 419.; Case Concerning the Application of the Convention on the Prevention and Punishment of the Crime of Genocide (Croatia v. Serbia), Judgement, ICJ Reports (2015), str. 61., para. 128.

3 Vidi rezoluciju Opće skupštine UN-a o prihvaćanju Nacrta članaka Komisije za međunarodno pravo o odgovornosti međunarodnih organizacija, kao i tekst članaka dodan uz Rezoluciju: Resolution adopted by the General Assembly on 9 December 2011 (on the report of the Sixth Committee (A/66/473), Responsibility of International Organizations, General Assembly, Official Records, Sixty-sixth Session, 27 February 2012, UN Doc. A/RES/66/100 (2012).

4 Rao, P. S., United Nations Responsibility from Authorizing the Use of Force, u: Ragazzi, M. (ur.), Responsibility of International Orgnizations: Essays in Memory of Sir Ian Brownlie, Martinus Nijhoff Publishers, Leiden/Boston, 2013., str. 409.

5 Shraga, D., ILC Articles on Responsibility of International Organizations: The Interplay between the Practice and the Rule (a View from the United Nations), u: Ragazzi, ibid., str. 201.Vidi i Komentar Nacrta članaka o odgovornosti međunarodnih organizacija u Draft Articles on the Responsibility of International Organizations, with Commentaries 2011, Report of the International Law Commission on the Work of Its Sixty-third Session, General Assembly Official Records, Sixty-sixth Session, Supplement No. 10 (A/66/10) (2011), str. 2., para. 5. (u daljnjem tekstu: Komentar Nacrta 2011).

6 Rao, op. cit. u bilj 4, str. 409.

7 Komentar Nacrta 2011, supra u bilj. 5. 
primjene. Prema odredbi čl. 7. "Ponašanje organa države ili organa ili agenta međunarodne organizacije koji je stavljen na raspolaganje drugoj međunarodnoj organizaciji smatra se prema međunarodnom pravu činom te druge međunarodne organizacije ako ta međunarodna organizacija provodi efektivnu kontrolu nad tim ponašanjem." ${ }^{8}$ Ta se odredba primjenjuje, prema tumačenju same Komisije za međunarodno pravo, u slučajevima kad države članice UN-a daju svoje vojne kontingente na raspolaganje toj organizaciji za sudjelovanje u mirovnim operacijama pa se postavlja pitanje, koje je u središtu našeg istraživanja, kojem se subjektu međunarodnoga prava može pripisati ponašanje tako ustupljenog organa: državi koja ga je ustupila međunarodnoj organizaciji ili međunarodnoj organizaciji kojoj je ustupljen.

Za razliku od čl. 6. Nacrta 2011 koji propisuje da će se ponašanje organa ili agenta međunarodne organizacije smatrati činom te organizacije ili čl. 8. Nacrta 2011 koji govori o pripisivosti ponašanja organa ili agenta međunarodne organizacije počinjenog ultra vires ili pak čl. 9. koji međunarodnoj organizaciji pripisuje ponašanje koje ta organizacija prizna i prihvati kao svoje, ${ }^{9}$ a koje sve odredbe omogućuju relativno jasno utvrđivanje pripisivosti, primjena odredbe čl. 7. u praksi je pokazala određene nedostatke i nejasnoće. Ključna pitanja koja su se pojavila pred međunarodnim sudovima, ali i u teoriji međunarodnoga prava su sljedeća: znači li stavljanje na raspolaganje organa države potpun ili samo djelomični prestanak institucionalne ili faktične povezanosti države i tog organa; ima li standard efektivne kontrole, koji je explicite naveden kao mjerodavan u tekstu čl. 7., sadržaj analogan onome koji je utvrđen u presudama Međunarodnog suda (Nicaragua i Genocide) ${ }^{10}$ kod pitanja pripisivosti ponašanja privatnih osoba ili skupina osoba državi; i propisuje li čl. 7., barem implicitno, mogućnost dvostruke ili višestruke pripisivosti nekog ponašanja istovremeno i državi koja je ustupila svoj organ međunarodnoj organizaciji za potrebe mirovne operacije.

U nastavku rada analizirat ćemo odredbu čl. 7. Nacrta 2011 stavljajući naglasak na pripadajuće komentare Komisije za međunarodno pravo (infra, poglavlje 2.). Zatim ćemo kroz prikaz dosadašnje prakse Europskog suda za ljudska prava, kao i presuda nekih državnih sudova (Nizozemske, Belgije i Ujedinjene Kraljevine) izložiti ključne probleme koji su se pojavili pri odlučivanju o pripisivosti protupravnog ponašanja počinjenih u okviru mirovnih operacija pod vodstvom UN-a (infra, poglavlje 3.). Kritički ćemo se osvrnuti na standarde kontrole koji su kao osnova pripisivosti primijenjeni u analiziranim odlukama i ponuditi odgovore na ta pitanja, a koji bi u budućnosti mogli doprinijeti jasnijoj, ujednačenoj, a time i učinkovitijoj primjeni pravila o odgovornosti međunarodnih organizacija (poglavlje 4.).

\section{POLJE PRIMJENE ČL. 7. NACRTA ČLANAKA O ODGOVORNOSTI MEĐUNARODNIH ORGANIZACIJA}

Za razliku od odredaba o pripisivosti određenog ponašanja državi radi utvrđivanja njezine odgovornosti za međunarodno protupravne čine koje pokrivaju različite situacije u kojima je,

8 Vidi odredbu čl. 7. Nacrta 2011, UN Doc. A/RES/66/100 (2012).

9 Usporedi s člancima 4., 7. i 11. Nacrta 2001, UN Doc. A/RES/56/83 (2002).

10 Vidi Military and Paramilitary Activities in and against Nicaragua (Nicaragua v. United States of America), Merits, Judgement, ICJ Reports (1986), str. 14. i ICJ Reports (2007), supra u bilj. 2. 
osim postupanja njezinih organa državi, moguće pripisati i one čine koje u određenim okolnostima počine privatne osobe ili skupine osoba, odredbe o pripisivosti čina međunarodnim organizacijama relativno su malobrojne. Tako odredba čl. 6. propisuje da se ponašanje organa ili agenata neke međunarodne organizacija ima pripisati upravo toj organizaciji, ${ }^{11}$ odredbom čl. 8. međunarodnoj organizaciji pripisuju se i oni čini koji su počinjeni ultra vires. ${ }^{12} \mathrm{~A}$ odredbom čl. 9. određena je pripisivost onih ponašanja koje međunarodna organizacija prizna i prihvati kao svoje. ${ }^{13}$

Specifična je, međutim, situacija koju predviđa odredba čl. 7. Nacrta 2011 koja govori o pripisivosti ponašanja u slučajevima suradnje između neke države i međunarodne organizacije u kontekstu stavljanja na raspolaganje državnih organa nekoj međunarodnoj organizaciji. Uspoređujući tu odredbu s odredbom čl. 6. Nacrta 2001, stječe se dojam da je riječ o istim ili sličnim situacijama. Međutim, prema odredbi čl. 6. organ države koji je ustupljen drugoj državi radi izvršavanja javnih ovlasti te države izjednačava se s obzirom na pravni status sa statusom državnog organa te druge države te djeluje isključivo pod njezinim usmjerenjem i kontrolom. ${ }^{14}$ U sličnoj situaciji, kad se organ države (ili međunarodne organizacije) u potpunosti ustupa drugoj međunarodnoj organizaciji pa djeluje kao njezin organ, primijenit će se odredba čl. 6 . Nacrta 2011 tako da se djela tog organa automatski pripisuju organizaciji kojoj je ustupljen. ${ }^{15}$

Odredba čl. 7. Nacrta 2011 odnosi se na situaciju u kojoj organ koje se ustupa drugoj međunarodnoj organizaciji zadržava status organa države koja ga je ustupila. ${ }^{16}$ To je, na primjer, slučaj oružanih snaga koje država kao svoje organe ustupa UN-u radi sudjelovanja u mirovnim operacijama, a nad kojima zadržava određene nadležnosti, poput disciplinskih ovlasti i kaznenu jurisdikciju. ${ }^{17}$ Sama Komisija za međunarodno pravo naglasila je da zadržavanje određenih ovlasti države nad svojim kontingentima u mirovnim operacijama posljedično utječe i na pripisivanje ponašanja tako ustupljenih kontingenata između države i međunarodne organizacije. $^{18}$

Drugo je pitanje, međutim, ono o distribuciji odgovornosti između tih subjekata, bez obzira na rezultat pripisivosti ponašanja ustupljenih organa. U tom kontekstu važno je spomenuti praksu UN-a koji s državama sklapaju tzv. model sporazume u kojima razrađuju sva relevantna pitanja vezana uz angažman pojedinih država članica što se tiče njihovih vojnih kontingenata za konkretnu mirovnu operaciju (broj vojnog i civilnog osoblja, opreme, detalje o zapovjednoj

\footnotetext{
11 Vidi odredbu čl. 6. Nacrta 2011, UN Doc. A/RES/66/100 (2012).

12 Vidi odredbu čl. 7. Nacrta 2011, ibid.

13 Vidi odredbu čl. 9. Nacrta 2011, ibid.

14 Komentar Nacrta 2001, supra u bilj. 1, str. 44., paras. 1.-2.

15 Komentar Nacrta 2011, supra u bilj. 5, str. 19.-20., para. 1.; Shraga, op. cit. u bilj. 5, str. 203.

16 Komentar Nacrta 2011, ibid.

17 Ibid. i str. 21., para. 7. Neki autori trupe mirovnih misija UN-a nazivaju hibridnima (one su istovremeno i snage UN-a i snage određene države). Vidi, primjerice, u: Gal-Or, N., Ryngaert, C., From Theory to Practice: Exploring the Relevance of the Draft Articles on the Responsibility of International Organizations (DARIO) - The Responsibility of the WTO and the UN, German Law Journal, sv. 13, 2012., str. 529. Dannenbaum u tom pogledu navodi da kod mirovnih misija dolazi do "bifurkacije institucionalnih prava i odgovornosti". Vidi Dannenbaum, T., Translating the Standard of Effective Control into a System of Effective Accountability: How Liability Should be Apportioned for Vioaltions of Human Rights by Member State Troop Contingents Serving as United Nations Peacekeepers, Harvard International Law Journal, sv. 51, 2010., str. 116.
} 
strukturi i slično). ${ }^{19} \mathrm{U}$ takvim model sporazumima navodi se da države koje doprinose svoje vojne kontingente zadržavaju kaznenu jurisdikciju u slučaju optužbi za kaznena djela počinjena od strane vojnog osoblja koje sudjeluje u konkretnoj mirovnoj operaciji. ${ }^{20}$ Druga odredba takvih sporazuma koja određuje odgovornost UN-a prema trećoj strani, uz pravo na naknadu od države u slučaju da je gubitak, šteta, smrt ili ozljeda nastala zbog krajnje nepažnje ili namjere ustupljenog organa te države, ${ }^{21}$ može se tumačiti kao dogovor o podjeli odgovornosti između te države i UN-a. ${ }^{22} \mathrm{~S}$ druge strane, samo pitanje pripisivosti njihova ponašanja, kako ćemo vidjeti, ovisi o konkretnim okolnostima slučaja, različitim vrstama mirovnih operacija, o dobivenom mandatu, i u konačnici o različitim interpretacijama pravila o pripisivosti pred državnim i međunarodnim sudovima.

Drugi dio odredbe čl. 7. Nacrta 2011 precizira uvjete pod kojima se ponašanje tako ustupljenog organa može pripisati međunarodnoj organizaciji. Komisija za međunarodno pravo u svom komentaru izrijekom kaže da se kriterij za pripisivost temelji na faktičnoj (stvarnoj) kontroli koja se provodi nad ponašanjem u pitanju. ${ }^{23}$ Nužno je pritom uzeti u obzir sve okolnosti slučaja, kao i konkretan kontekst tih okolnosti. ${ }^{24}$

Upotreba termina efektivna kontrola u odredbi čl. 7. nužno nas upućuje na usporedbu sa standardom kontrole koji je propisan kao kriterij pripisivosti ponašanja pojedinaca ili skupine pojedinaca državi, sukladno odredbi čl. 8. Nacrta 2001. ${ }^{25}$ Ta se odredba odnosi na iznimnu situaciju pripisivosti čina osoba čije ponašanje se inače, prema pravilima međunarodnog prava, ne bi moglo pripisati državi, s obzirom na to da njihovo djelovanje ostaje izvan okvira organizacije državne vlasti, osim ako su ispunjene određene pretpostavke: djelovanje prema instrukcijama, odnosno smjernicama ili pod kontrolom države. Konkretan sadržaj kontrole nužan za primjenu spomenute odredbe Komisija za međunarodno pravo nije propisala. Samo je dala općenitu uputu da je u procjeni standarda kontrole potrebno uzeti u obzir stvarnu vezu koja postoji između privatnih osoba i same države, ${ }^{26}$ kao i da je potrebno uzeti u obzir okolnosti svakog pojedinog slučaja. ${ }^{27}$

Mjerodavnost testa efektivne kontrole potvrđena je u praksi Međunarodnog suda koji je odlučivao mogu li se, s jedne strane, povrede međunarodnog humanitarnog prava počinjene od strane paravojne skupine Contras u Nikaragvi pripisati SAD-u i time utvrditi međunarodna odgovornost te države (presuda iz 1986. godine), a s druge strane, je li Srbija odgovorna

19 Model Agreement between the United Nations and Member States contributing personnel and equipment to United Nations peacekeeping operations, Report of the Secretary-general, UN Doc. A/46/185 (23 May 1991).

西
Contribution Agreement between the United Nations and Participating State Contributing Resources to the United Nations Peace-Keeping
Operation, UN Doc. A/50/995, Annex, čl. 9. (9 July 1996). Identična odredba nalazi se i u Model Memorandum of Understanding between the United Nations and Participating State Contributing Resources to the United Nations Peacekeeping Operation, UN Doc. A/51/967, Annex, čl. 9. (27 August 1997). Vidi i Komentar Nacrta 2011, supra u bilj. 5, str. 20., para. 3.

23 Komentar Nacrta 2011, supra u bilj. 5, str. 20., para. 4.

24 Ibid. ta osoba ili skupina osoba de facto djeluje prema instrukcijama, ili prema smjernicama ili pod kontrolom države tijekom tog ponašanja." Vidi UN Doc. A/RES/56/83 (2002).

26

Ibid., str. 48., para. 5. 
za protupravna djela nedržavnog entiteta Republike Srpske na području Bosne i Hercegovine (presuda iz 2007. godine). Međunarodni je sud u spomenutim odlukama utvrdio sljedeće: iako je dokazano da su Sjedinjene Američke Države financirale, organizirale, uvježbavale, opskrbljivale i opremale pripadnike skupine Contras te sudjelovale u planiranju njihovih vojnih operacija, nije utvrđeno da je ta država ujedno provodila efektivnu kontrolu nad njihovim aktivnostima. ${ }^{28}$ Također, Međunarodni sud nije smatrao dokazanim da su genocid u Srebrenici počinile osobe koje su imale status organa države Srbije, a isto tako da Srbija nije provodila efektivnu kontrolu nad operacijama tijekom kojih je počinjen genocid nad bošnjačkim stanovništvom. ${ }^{29}$

Pa ipak, svrha kojoj test kontrole služi nije jednaka u dvama Nacrtima. Dok o pitanju kontrole prema Nacrtu 2001 ovisi odgovor na pitanje mogu li se djela osoba ili skupina osoba, koje nisu državni organi, uopće pripisati državi, odredba o efektivnoj kontroli prema čl. 7. Nacrta 2011 odnosi se na pitanje koji od potencijalnih subjekata (država ili međunarodna organizacija, ili oba subjekta) provodi efektivnu kontrolu nad konkretnim ponašanjem organa koji je stavljen na raspolaganje međunarodnoj organizaciji. ${ }^{30}$

Navedena razlika proizlazi iz prirode odnosa između, s jedne strane, države i privatnih osoba ili skupina osoba, koji odnos, ako se promatra u kontekstu odredbe čl. 8. Nacrta 2001, nikada nije formalne naravi pa se stoga pripisivost njihova ponašanja državi procjenjuje isključivo uzimajući u obzir stvarnu vezu koja među njima postoji, odnosno stvarnu kontrolu države nad konkretnim ponašanjem. ${ }^{31} \mathrm{~S}$ druge strane, uobičajeno je da se države i međunarodne organizacije, ili, pak, dvije ili više međunarodnih organizacija povezuju na formalan način, pa je jasno da kontrola jednog od subjekata uvijek postoji. ${ }^{32}$

28 ICJ Reports (1986), supra u bilj. 10, str. 64.-65., para. 115

29 ICJ Reports (2007), supra u bilj. 2, str. 214.-215., para. 413. Međunarodni je sud zaključio samo da je Srbija odgovorna zato što nije spriječila genocid u Srebrenici, odnosno zato što nije kaznila počinitelje tog zločina. Vidi ibid., str. 225.-226., para. 438. i str. 229., para. 450. Kritike na visoko postavljene kriterije testa efektivne kontrole u praksi Međunarodnog suda iznesene su u presudama Međunarodnog tribunala za bivšu Jugoslaviju (ICTY), koji je u praksu uveo fleksibilniji kriterij radi utvrđivanja pripisivosti - test sveukupne kontrole (overall control). Vidi, primjerice, Prosecutor v. Duško Tadić, Appeals Chamber Judgement, Case No. IT-94-1-A (1999), str. 47.-48., paras. 115.-117. et seq. Kritike na dva spomenuta testa kontrole primijenjena u praksi međunarodnih sudova izneseni su i u radovima teorietičara međunarodnog prava. Tako, primjerice, Cassese, A., The Nicaragua and Tadić Tests Revisited in Light of the ICJ Judgement on Genocide in Bosnia, European Journal of International Law, sv. 18, 2007.; Milanović, M., State Responsibility for Genocide, European Journal of International Law, sv. 17, 2006.; Boon, K. E., Are Control Tests Fit for the Future? The Slippage Problem in Attribution Doctrines, Melbourne Journal of International Law, sv. 15, 2014.

30 Komentar Nacrta 2011, supra u bilj. 5, str. 21., para. 5. Vidi i: Boon, op. cit. u bilj. 29, str. 354. et seq.; Dannenbaum, op. cit. $\mathrm{u}$ bilj. 17, str. 155.-156.; Montejo, B., The Notion of 'Effective Control 'under the Articles on the Responsibility of International Organizations, u: Ragazzi, op. cit. u bilj. 4, str. 392.-393.

32 Kao primjer Boon navodi upravo mirovne operacije u kojima UN angažira oružane snage drugih država. S obzirom na formalnu prirodu takvog angažmana, pripadnici nacionalnih kontingenata nikada ne djeluju kao iregularne skupine (poput onih na koje se primjenjuje čl. 8. Nacrta 2001). S obzirom na to da oni zadržavaju status organa svojih nacionalnih vlada, pripisivost njihova ponašanja ovisi o pitanju kontrole. Vidi Boon, op. cit. u bilj. 29, str. 355. Glavni tajnik UN-a 1996. godine ustvrdio je da je upravo kriterij efektivne kontrole odlučujući faktor prema kojem se odlučuje o odgovornosti za čine počinjene u zajedničkim operacijama, u situacijama kad ne postoje formalni sporazumi između UN-a i država koje doprinose svoje vojne kontingente. Ako, pak, sporazumi o modalitetima suradnje između UN-a i država u zajedničkim operacijama postoje, istaknuto je da međunarodna odgovornost za čine ustupljenih kontingenata leži kod onoga kome je, sukladno sporazumu, dodijeljena ovlast operativnog zapovijedanja i kontrole (operational command and control). Vidi Financing of the United Nations Protection Force, the United Nations Confidence Restoration Operation in Croatia, the United Nations Preventive Deployment Force and the United Nations Peace Forces Headquarters, Report of the Secretary-General, UN Doc. A/51/389, str. 6., para. 18. (20 September 1996). Glavni tajnik ističe da vrijedi priznato načelo međunarodne odgovornosti da u koordiniranim vojnim operacijama odgovornost za štetu nastalu zbog kršenja međunarodnog humanitarnog prava snosi onaj tko ima ovlast efektivnog zapovijedanja i kontrole nad određenom operacijom ili specifičnim djelovanjem. Vidi ibid., para. 19. 
S obzirom na to da broj mirovnih operacija neprestano raste, a nažalost, nisu rijetke ni situacije kršenja pravila međunarodnog humanitarnog prava kao i ljudskih prava (poput seksualnog zlostavljanja, krijumčarenja žena i djece, zlostavljanja djece, uskraćivanja prava na odvjetnika, protupravnog pritvaranja civila, čak i mučenja), ${ }^{33}$ sve se češće pred državnim i međunarodnim tijelima raspravlja o odgovornosti za protupravne čine počinjene tijekom mirovnih operacija. U svakom je slučaju potrebno najoštrije osuditi takva kršenja ljudskih prava od strane onih koji su angažirani upravo s ciljem njihove zaštite pa se možemo složiti s ocjenom da je takva destruktivna pojava odraz "pokvarenosti međunarodnog sustava". ${ }^{34}$

Iako se slučajevi iz sudske prakse Europskog suda za ljudska prava (u daljnjem tekstu: ESLJP), koji se tiču pitanja odgovornosti za protupravne čine počinjene tijekom mirovnih operacija, uglavnom odnose na razdoblje prije usvajanja Nacrta 2011, prikazat ćemo ih radi analize različitih interpretacija sadržaja i značenja testa efektivne kontrole. Vidjet ćemo da je standard kontrole kao kriterij za pripisivost u mirovnim operacijama (UN-a i NATO-a) podložan različitim tumačenjima što, nažalost, doprinosi pravnoj nesigurnosti i izaziva kritike među teoretičarima međunarodnog prava. ${ }^{35}$

\section{PRAKSA EUROPSKOG SUDA ZA LJUDSKA PRAVA I NEKIH NACIONALNIH SUDOVA}

\subsection{SLUČAJ BEHRAMI I SARAMATI}

ESLJP u Strasbourgu u nekoliko je slučajeva imao priliku razmatrati pitanje odgovornosti država stranaka Europske konvencije za zaštitu ljudskih prava i temeljnih sloboda iz 1950. godine $^{36}$ (u daljnjem tekstu: Europska konvencija) za kršenje odredaba te Konvencije, i to u kontekstu sudjelovanja oružanih snaga tih država u različitim mirovnim operacijama, bilo pod okriljem UN-a (npr. UNMIK na Kosovu), bilo u okviru koalicije sastavljene od kontingenata oružanih snaga nekoliko država (npr. u Iraku). Vodeći se standardom efektivne kontrole koji je zagovarala Komisija za međunarodno pravo, iako je u vrijeme donošenja presude Nacrt

33 O seksualnom iskorištavanju i zlostavljanju u misiji UN-a u Kongu (MONUC) tijekom 2004. godine vidi Investigation by the Office of Internal Oversight Services into allegations of sexual exploitation and abuse in the United Nations Organization Mission in the Democratic Republic of the Congo, Report of the Secretary-General on the activities of the Office of International Oversight Services, UN Doc. A/59/661 (5 January 2005). O iskorištavanju djece izbjeglica u Liberiji, Gvineji i Sierra Leoneu vidi Sexual Violence and Exploitation: The Experience of Refugee Children in Liberia, Guinea and Sierra Leone, Report of Assessment Mission Carried out from 22 October to 30 November 2001, United Nations High Commissioner for Refugees, Save the Children - UK, January 2002, https://www.parliament.uk/documents/commons-committees/international-development/2002-Report-ofsexual-exploitation-and-abuse-Save\%20the\%20Children.pdf (8. studenog 2018.). O seksualnom zlostavljanju žena u Somaliji koje su počinili pripadnici mirovne misije AMISOM vidi https://www.rt.com/news/186100-somalia-peacekeepers-rape-women/ (8. studenog 2018.). Md. K., Human Rights Violations by UN Peacekeepers: An End to Impunity, Security and Human Rights, sv. 25, 2014., str. 130. et seq. Slično i Montejo, op. cit. u bilj. 30, str. 404. 
članaka o odgovornosti međunarodnih organizacija bio tek u izradi, ESLJP je imao zadatak odlučiti jesu li za navodne povrede Europske konvencije odgovorne države koje su sudjelovale u spomenutim operacijama. S obzirom na prirodu angažmana tih država ESLJP je raspravljao o pripisivosti ne samo tim državama, nego i UN-u, odnosno drugoj međunarodnoj organizaciji pod čijim okriljem se mirovna operacija provodila.

Odluka ESLJP-a u slučajevima Behrami i Saramati ${ }^{37}$ izazvala je mnogo kritika među teoretičarima međunarodnog prava. ${ }^{38}$ Naime, odlučujući o dopuštenosti obje tužbe, ESLJP je kao o prethodnom pitanju prvo raspravljao o postojanju nadležnosti ratione personae ovisno o mogućnosti pripisivanja konkretnih čina tuženim državama počinjenih pod okriljem UNa, odnosno o odnosu između Europske konvencije i djelovanja UN-a prema glavi VII. Povelje UN-a. ${ }^{39}$ Ono što se pokazalo najproblematičnijim dijelom odluke bilo je uvođenje dotad nepoznatog i, prema našem mišljenju, nejasnog koncepta kontrole radi utvrđivanja pripisivosti ponašanja pripadnika UNMIK-a, odnosno KFOR-a dvjema međunarodnim organizacijama (UN-u i NATO-u). ESLJP je uveo standard vrhovne (konačne) vlasti i kontrole (ultimate authority and control).

Konkretno, ESLJP je raspravljao o tome mogu li se djela i propusti pripadnika UNMIK-a, kao pomoćnog organa UN-a i KFOR-a na Kosovu pripisati državama o čijim državljanima je u konkretnim slučajevima bila riječ. Drugim riječima, bilo je potrebno odlučiti jesu li Francuska (u slučaju Behrami) odnosno Francuska i Norveška (u slučaju Saramati) odgovorne za povrede svojih obveza iz Europske konvencije. Međutim, umjesto utvrđivanja koji su od uključenih subjekata (UN, NATO ili države koje su svoje oružane snage stavile UN-u na raspolaganje) provodili efektivnu kontrolu nad UNMIK-om i KFOR-om, sukladno odredbi tadašnjeg čl. 5. Nacrta o odgovornosti međunarodnih organizacija (koji odgovara odredbi čl. 7. Nacrta 2011), ${ }^{40}$ ESLJP je ne samo zanemario test efektivne kontrole, nego i pitanje pripisivosti pripadnika

37 Behrami v. France, Application No. 71412/01 and Saramati v. France, Germany and Norway, Application No. 78166/01, Grand Chamber of the European Court of Human Rights, Decision as to the Admissibility (2007). U slučaju Behrami tužitelji Agim i Bekim Behrami tužili su Francusku zbog povrede odredbe čl. 2. Europske konvencije (koja jamči pravo na život), zbog smrti, odnosno teške tjelesne ozljede dvojice sinova Agima Behramija koje su navodno prouzročene propustom pripadnika francuskih snaga KFOR-a da označe i razminiraju nedetonirane bombe zaostale na području Mitrovice nakon zračnih napada NATO-a tijekom 1999. godine. Detaljnije o činjenicama slučaja vidi ibid., str. 4.-5., paras. 5.-7., i str. 20., para. 63. Slučaj Saramati tiče se Ruzhdija Saramatija, stanovnika Kosova kojeg su pripadnici policije UNMIK-a 2001. godine uhitili pod optužbom za ubojstvo te nezakonito posjedovanje oružja. Nakon odluke Vrhovnog suda o Saramatijevu puštanju na slobodu, odlukom norveškog generala, zapovjednika KFOR-a, Saramati je ponovno uhićen zbog sigurnosnih razloga. Zadržavanje Saramatija produljeno je i nakon što je francuski general preuzeo zapovjedništvo KFOR-a. Saramati je suđen za pokušaj ubojstva, ali i oslobođen je nekih optužbi te je premješten u pritvor u Prištinu u nadležnosti UNMIK-a. Odlučujući o žalbi protiv te presude Vrhovni je sud Kosova odredio ponovno suđenje te puštanje Saramatija na slobodu. Saramati je podnio tužbu ESLJP-u protiv Francuske, Norveške i Njemačke (od tužbe protiv Njemačke naposljetku je odustao, vidi ibid., str. 20., paras. 64.-65.) pozivajući se na povredu odredbe čl. 5. Europske konvencije (koja jamči pravo na slobodu i sigurnost) u vezi s odredbom čl. 13. (o pravu na djelotvoran pravni lijek), te na povredu odredbe čl. 6. (koja jamči pravo na pošteno suđenje). Detaljnije o činjenicama slučaja vidi ibid., str. 5.-6., paras. 8.-17., str. 20., para. 62.

Vidi npr. Bell, C. A., Reassessing Multiple Attribution: the International Law Commission and the Behrami and Saramati Decision, N.Y.U. Journal of International Law and Politics, sv. 42, 2009./2010.; Boon, op. cit. u bilj. 29, str. 357. et seq.; Canto Lopez, M., Towards Dual or Multiple Attribution: the Strasbourg Court and the Liability of Contracting Parties' Troops Contributed to the United Nations, International Organizations Law Review, sv. 10, 2013., str. 193. et seq.; Mujezinović Larsen, K., 'Neither Effective Control nor Ultimate Authority and Control': Attribution of Conduct in Al-Jedda, Military Law and the Law of War Review, sv. 50, 2011. str. 347. et seq.; Sari, A., Jurisdiction and International Responsibility in Peace Support Operations: the Behrami and Saramati Cases, Human Rights Law Review, sv. 8, 2008., str. 151. et seq. Behrami v. France (2007), supra u bilj. 37, str. 41., para. 146. 
oružanih snaga Francuske i Norveške kao organa tih država, što bi bilo sukladno odredbi čl. 4. Nacrta 2001 o pripisivanju čina državnih organa državi čiji su to organi.

Konstrukcijom u praksi dotad nepoznatog testa vrhovne vlasti i kontrole UN-a preko Vijeća sigurnosti, ESLJP je zaključio da se djela i propusti UNMIK-a, odnosno KFOR-a mogu pripisati jedino UN-u, ${ }^{41}$ ne ispitujući pritom koji je eventualni doprinos uključenih država i stupnja kontrole koje su one provodile nad pripadnicima nacionalnih kontingenata u okviru UNMIK-a i KFOR-a u konkretnom događaju. ${ }^{42}$ Sud je zaključio da je Vijeće sigurnosti UN-a svoje ovlasti samo delegiralo na države članice na temelju rezolucije 1244 (1999), a da je Vijeće (odnosno UN) zadržalo vrhovnu vlast i kontrolu, zbog čega je naposljetku i odlučeno da se čini i propusti pripadnika UNMIK-a kao pomoćnog organa Vijeća sigurnosti i KFOR-a mogu pripisati UNu. ${ }^{43}$ Slijedom toga, ESLJP je odbacio tužbe u slučajevima Behrami i Saramati zbog nepostojanja nadležnosti ratione personae. ${ }^{44}$

Iako u odluci nisu navedeni jasni argumenti koji bi opravdali uvođenje koncepta vrhovne vlasti i kontrole nasuprot efektivnoj kontroli, ${ }^{45}$ ESLJP je pokušao obrazložiti osnovu zadržavanja vrhovne vlasti i kontrole na razini UN-a, a čiji pravni temelj proizlazi iz rezolucije Vijeća sigurnosti 1244 (1999). ${ }^{46}$ Prije svega, glava VII. Povelje UN-a ovlašćuje Vijeće sigurnosti da na države članice i određene međunarodne organizacije prenese određene ovlasti; drugo, riječ je bila o ovlastima koje se mogu prenijeti; treće, rezolucija 1244 (1999) izričito je predvidjela prenošenje ovlasti; četvrto, u Rezoluciji je u dovoljnoj mjeri definirano trajanje prenesenih ovlasti; i posljednje, vodstvu KFOR-a određena je obveza podnositi izvješća Vijeću sigurnosti kako bi ono moglo provoditi svoju vrhovnu vlast i kontrolu. ${ }^{47}$ Sukladno tome, zaključeno je da

41 ESLJP je primijenio sljedeću strukturu odlučivanja: prije svega, utvrdio je sadržaj mandata KFOR-a i UNMIK-a, odnosno utvrdio u čiju nadležnost su ulazile aktivnost razminiranja i pritvaranja; zatim je utvrdio mogu li se radnje pritvaranja (u slučaju Saramati) odnosno propust UNMIK-a (u slučaju Behrami) pripisati UN-u, sukladno pravnom okviru njihova djelovanja dodijeljenog po glavi VII. Povelje UN-a; i posljednje, bilo je potrebno odlučiti o postojanju ili nepostojanju nadležnosti ratione personae. Detaljnije vidi u Behrami i Saramati (2007), supra u bilj. 37, str. 34. et seq., paras. 121. et seq., str. 43., para. 151.

42 Iako je utvrđeno da su države zadržale određene ovlasti glede pripadnika svojih kontingenata (npr. disciplinske, sigurnosne i logističke ovlasti te isključivu kaznenu jurisdikciju) te se zato NATO-ove ovlasti ne mogu smatrati isključivima, ESLJP je došao do zaključka da takav doprinos država ne umanjuje efektivnost operativne kontrole koju je provodio NATO. Opširnije vidi ibid., str. 39.-40., paras. 137.-141. Što se tiče UNMIK-a, Sudu je bilo dovoljno utvrditi da je riječ bila o pomoćnom organu UN-a osnovanom na temelju glave VII. Povelje UN-a tako da se sporni događaji "u načelu" mogu pripisati UN-u. Vidi ibid., str. 40.-41., paras. 142.-143.

Ibid.

44 Ibid., str. 41.-43., paras. 144.-152. I u nekoliko sljedećih odluka ESLJP je, pozivajući se na obrazloženje izneseno u slučajevima Behrami i Saramati, odbacio podnesene tužbe zbog nepostojanja osobne nadležnosti. Vidi: Kasumaj v. Greece, Application No. 6974/05, European Court of Human Rights, Decision as to the Admissibility (2007) i Gajić v. Germany, Application No. 31446/02, European Court of Human Rights, Decision as to the Admissibility (2007). U slučaju Berić and Others v. Bosnia and Herzegovina ESLJP je objašnjenje iz odluke u slučajevima Behrami i Saramati u pogledu pripisivosti ponašanja i nadležnosti ratione personae primijenio i na slučaj međunarodne civilne uprave uspostavljene u BiH. Vidi Berić and Others v. Bosnia and Herzegovina, Applications Nos. 36357/04, 36360/04, 38346/04, 41705/04, 45190/04, 45578/04, 45579/04, 45580/04, 91/05, $97 / 05,100 / 05,101 / 05,1121 / 05,1123 / 05,1125 / 05,1129 / 05,1132 / 05,1133 / 05,1169 / 05,1172 / 05,1175 / 05,1177 / 05$, 1180/05, 1185/05, 20793/05 and 25496/05, European Court of Human Rights, Decision as to the Admissibility (2007).

45 ESLJP doduše u nekoliko navrata spominje efektivnu kontrolu, ali ne u kontekstu pripisivosti, nego u kontekstu rasprave o eksteritorijalnoj primjeni Europske konvencije. Vidi Behrami i Saramati (2007), supra u bilj. 37, str. 21.-23., paras. 68.-71.

46 Rezolucija Vijeća sigurnosti 1244 (1999) pravni je temelj prisutnosti sigurnosnih snaga KFOR-a na Kosovu (pod okriljem UN-a, ali uz značajno sudjelovanje NATO-a) te privremene međunarodne uprave UNMIK na Kosovu (United Nations Interim Administration Mission in Kosovo), s mandatom za izgradnju i jačanje civilnih institucija, demokratizaciju društva, administrativne i pravosudne poslove te osiguranje humanitarne pomoći. Rezolucijom je predviđena bliska suradnja KFOR-a i UNMIK-a radi ostvarivanja zadanih ciljeva. Detaljnije o mandatu UNMIK-a i KFOR-a vidi u: UN Security Council Resolution, UN Doc. S/RES/1244 (1999). 
je KFOR provodio zakonito delegirane ovlasti Vijeća sigurnosti na temelju glave VII. Povelje te su, prema tome, njegova djela u načelu pripisiva $\mathrm{UN}-\mathrm{u} .{ }^{48}$

Čini nam se da je ESLJP primjenom koncepta vrhovne vlasti i kontrole zaobišao strože zahtjeve koji su postavljeni testom efektivne kontrole koje je postavila Komisija za međunarodno pravo, a da je pojam vrhovne vlasti i kontrole prema svojem sadržaju bliži pojmu sveukupne kontrole (overall control) uvedenom u praksi ICTY-a. ${ }^{49}$ Osim toga, smatramo značajnim propustom Suda to što je u odluci u slučajevima Behrami i Saramati ignoriran stvarni doprinos država, odnosno intenzitet kontrole koju su de facto zadržale nad pripadnicima nacionalnih kontingenata u provođenju ovlasti koje su im dodijeljene rezolucijom Vijeća sigurnosti. Odlukom o nepostojanju osobne nadležnosti došlo je do pojave praznine u pogledu odgovornosti država za ponašanje pripadnika nacionalnih kontingenata u okviru mirovnih operacija. Neki smatraju da je takvom odlukom ESLJP ograničio i svoje pravo, odnosno nadležnost raspravljati i odlučivati o budućim tužbama za međunarodno protupravne čine protiv država koji doprinose vojne kontingente u mirovnim operacijama. ${ }^{50}$

Stavljajući naglasak na formalne čimbenike i kriterije utvrđivanja kontrole, ${ }^{51}$ ESLJP je propustio priliku raspraviti mogućnost podjele odgovornosti između dva ili više subjekata, koja bi ovisila o stupnju (intenzitetu) kontrole koji se utvrdi na strani države odnosno međunarodne organizacije. Glavni tajnik UN-a naglasio je, a Komisija za međunarodno pravo također istaknula, da je upravo stupanj efektivne kontrole odlučujući u kontekstu zajedničkih operacija, osobito u slučaju kada ne postoje formalni sporazumi između UN-a i države ili država koje ustupaju svoje kontingente..$^{52}$

U praksi UN i države koje participiraju u mirovnim operacijama djeluju koordinirano i nikako ne neovisno jedni o drugima. Naime, u mirovnim operacijama zapovjednik UN-ovih snaga (UN Force Commander) ovlašten je provoditi operativnu kontrolu nad ustupljenim kontingentima, međutim, on pritom ima obvezu savjetovanja s državama o čijim je kontingentima riječ u pogledu planiranja operacija, odlučivanja, treniranja i sl. ${ }^{53} \mathrm{~S}$ druge pak strane, države ne smiju svoje vojne snage uputiti da djeluju protivno ciljevima i svrsi same operacije, odnosno bez suglasnosti zapovjednika UN-ovih snaga. ${ }^{54}$

48 Ibid., str. 40., para. 141. Ovakvo rezoniranje ESLJP-a izazvalo je kritike među teoretičarima međunarodnog prava. Vidi: Sari, op. cit. u bilj. 38, str. 162.-165.; Buchan, R., UN Peacekeeping Operations: When Can Unlawful Acts Committed by Peacekeeping Forces Be Attributed to the UN?, Legal Studies, sv. 32, 2012., str. 293. Opširnije o standardu sveukupne kontrole i praksi ICTY-a vidi u znanstvenim radovima navedenima supra u bilj. 29.

Bell, op. cit. u bilj. 38, str. 533.-534. Vidjet ćemo, međutim, da je kasnije donesena presuda u slučaju Al-Jedda barem donekle ispravila ove propuste implicitnim prihvaćanjem mogućnosti dvostruke i višestruke pripisivosti, čime je ublažena opasnost od nastanka praznine u pogledu odgovornosti država i međunarodnih organizacija za međunarodno protupravne čine. Vidi infra, u poglavlju 3.2.

Odnosno, pravni temelj prenesenih ovlasti, njihov sadržaj kao i pitanje dužnosti podnošenja izvješća. Vidi Behrami i Saramati (2007), supra u bilj. 37, str. 38.-39., para. 134.

Report of the Secretary-General, supra u bilj. 32, str. 6., paras. 17.-18.

Vidi UN Peacekeeping Operations: Principles and Guidelines, UN Department of Peacekeeping Operations, 2008., str. 52., 68., http:// www.refworld.org/docid/484559592.html (8. studenog 2018.). Slično i United Nations Peacekeeping Missions Military Special Forces Manual, UN Department of Peacekeeping Operations, 2015., str. 29., 50., http://dag.un.org/bitstream/handle/11176/89590/ United\%20Nations\%20Peacekeeping\%20Missions\%20Special \%20 Forces\%20Manual.pdf?sequence=1\&isAllowed=y, pristupljeno 8. studenog 2018. 
Dakle, vrhovna kontrola de facto se provodi zajednički i od strane zapovjednika vojnih snaga pojedine države i UN-a. Specijalni izvjestitelj Komisije za međunarodno pravo Giorgio Gaja napomenuo je da s obzirom na to da UN zapravo nikada nema isključivu kontrolu nad nacionalnim kontingentima, relevantan faktor u procjeni pripisivosti ponašanja njihovih pripadnika stupanj je kontrole koja se nad njima provodi. ${ }^{55}$ ESLJP u gore analiziranoj odluci nije, međutim, razmatrao u kojoj mjeri su pripadnici UNMIK-a odnosno KFOR-a zaista bili pod efektivnom kontrolom UN-a, odnosno Francuske i Norveške ili NATO-a, a radi procjene u kojoj se mjeri njihovo ponašanje može pripisati tim međunarodnim organizacijama i/ili državama te, u konačnici, odlučiti o njihovoj eventualnoj zajedničkoj odgovornosti. ${ }^{56}$ Test vrhovne vlasti i kontrole iz odluke u slučajevima Behrami i Saramati zapravo je u potpunosti lišen koncepta faktične kontrole nad konkretnim ponašanjem, što je u suprotnosti s odredbom čl. 7. Nacrta 2011, koja kao pretpostavku pripisivosti izričito propisuje efektivnu kontrolu.

U sljedećem primjeru, u slučaju Al-Jedda pred ESLJP-om, vidjet ćemo da iako ponovno nije definiran sadržaj testa efektivne kontrole odnosno vrhovne vlasti i kontrole, značajno je to što je ESLJP barem implicite priznao mogućnost dvostruke pripisivosti ponašanja državi i međunarodnoj organizaciji u kontekstu aktivnosti mirovnih operacija, odstupivši tako od stajališta iznesenih u odluci u slučajevima Behrami i Saramati. Iznesena stajališta u ovoj odluci bliža su stavovima specijalnog izvjestitelja Gaje koji je još tijekom rada na Nacrtu 2011 istaknuo da kontrola država i UN-a u mirovnim operacijama ostavlja prostor za razmatranje dvostruke pripisivosti njihova ponašanja. ${ }^{57}$

\subsection{SLUČAJ AL-JEDDA}

O slučaju Hilala Abdula-Razzaqa Ali Al-Jedde, koji je imao i iračko i britansko državljanstvo, a kojeg su u Iraku protupravno držali u pritvoru pripadnici britanskih oružanih snaga zbog sumnje da je bio uključen u terorističke aktivnosti, odlučivao je britanski Dom lordova. ${ }^{58} \mathrm{Al}$-Jedda je tvrdio da mu je protupravnim pritvaranjem od strane britanskih Koalicijskih snaga u Iraku povrijeđeno pravo na pravično suđenje zajamčeno odredbom čl. 5. Europske konvencije. ${ }^{59}$ Dom lordova trebao je odlučiti može li se čin protupravnog pritvaranja pripi-

55 Second Report on Responsibility of International Organizations, supra u bilj. 40, str. 22.-23., para. 48.

56 Leck, primjerice, ističe da su upravo pripadnici mirovnih snaga pod dvostrukom ili zajedničkom kontrolom UN-a i država koje doprinose svoje kontingente. Detaljnije vidi u: Leck, Ch., International Responsibility in United Nations Peacekeeping Operations: Command and Control Arrangements and the Attribution of Conduct, Melbourne Journal of International Law, sv. 10, 2009., str. 359. et seq. O propustima ESLJP-a u slučajevima Behrami i Saramati u kontekstu potencijalne višestruke pripisivosti vidi i Bell, op. cit. u bilj. 38, str. 501. et seq.

57 Second Report on Responsibility of International Organizations, supra u bilj. 40, str. 22.-23., para. 48.

58 R (on the Application of Al-Jedda) v. Secretary of State for Defence (2007), UKHL, 58.

59 Ibid., para. 1. Ovdje je bila riječ o eksteritorijalnoj primjeni Europske konvencije na temelju činjenice da je Ujedinjena Kraljevina provodila efektivnu kontrolu nad iračkim teritorijem. O primjeni odredaba Europske konvencije, odnosno nadležnosti u smislu čl. 1. Europske konvencije izvan teritorija država stranaka, dakle eksteritorijalno, vidi u odlukama ESLJP-a: Banković and Others v. Belgium and Others, Application No. 52207/99, Grand Chamber of the European Court of Human Rights, Decision as to the Admissibility (2001); Case of Ilascu and Others v. Moldova and Russia, Application No. 48787/99, European Court of Human Rights, Judgement (2004); Case of Issa and Others v. Turkey, Application No. 31821/96, European Court of Human Rights, Judgement (2004). O pitanju derogacije određenih obveza država stranaka u kontekstu eksteritorijalne primjene Europske konvencije, poglavito u pogledu sudjelovanja tih država u mirovnim operacijama vidi u: Mujezinović Larsen, op. cit. u bilj. 38, str. $359 .-363$. 
sati Ujedinjenoj Kraljevini ili UN-u, s obzirom na to da je rezolucijom Vijeća sigurnosti 1546 (2004) multinacionalna koalicija u Iraku dobila ovlast poduzimanja svih potrebnih mjera kako bi doprinijela održanju mira i stabilnosti u Iraku. ${ }^{60}$

Uspoređujući slučaj Al-Jedda s odlukom u slučajevima Behrami i Saramati Dom lordova je naveo da u dvama slučajevima postoji nekoliko bitnih razlika u pogledu pitanja pripisivosti u kontekstu UN-ovih mirovnih operacija i doprinosa oružanih snaga država. Prije svega, za razliku od UNMIK-a na Kosovu, koji je djelovao kao pomoćni organ UN-a na temelju rezolucije Vijeća sigurnosti, te KFOR-a na Kosovu koji je djelovao temeljem zakonito delegiranih ovlasti od strane Vijeća sigurnosti i sukladno danom mandatu, britanske snage u Iraku nisu bile raspoređene temeljem prenesenih ovlasti Vijeća sigurnosti, već su bile dijelom Koalicijskih snaga država predvođene SAD-om. ${ }^{61}$ Osnovna je razlika između dviju misija u tome što je KFOR na Kosovu djelovao kao misija koju je ovlastio, koju vodi i kojom upravlja UN (UN-run mission), dok je djelovanje britanskih snaga u Iraku bilo dijelom misije odobrene od strane UN-a (UN-authorized mission) ${ }^{62}$

Upravo na temelju tih razlika, ali i činjenice da Ujedinjena Kraljevina ni u jednom trenutku nije porekla odgovornost za ponašanje svojih snaga, a UN istovremeno za to ponašanje nije preuzeo odgovornost, zaključeno je da se protupravni čin ne može pripisati UN-u nego Ujedinjenoj Kraljevini. U obrazloženju odluke je navedeno da se ne može tvrditi da su britanske i američke snage bile pod efektivnim zapovjedništvom i kontrolom UN-a, odnosno da su britanske snage bile pod takvom kontrolom UN-a tijekom protupravnog pritvaranja iračkog/ britanskog državljanina Al-Jedde. ${ }^{63}$

U postupku pred ESLJP-om podržano je stajalište većine članova Doma lordova u pogledu pripisivosti ponašanja britanskih snaga u Iraku. ${ }^{64}$ Složivši se da su uloge UN-a na Kosovu i u Iraku bile različite, ${ }^{65}$ Sud je utvrdio da s obzirom na različitu ulogu i funkcije u Iraku Vijeće sigurnosti nije zadržalo niti efektivnu kontrolu niti vrhovnu vlast i kontrolu nad britanskim snagama te je zaključio: "Čin pritvaranja dogodio se u zatvorskom objektu u gradu Basri koji je

60 Buchan, op. cit. u bilj. 48, str. 293.-294. Vidi i UN Security Council Resolution, UN Doc. S/RES/1546 (2004), para. 10. i Text of Letters from the Prime Minister of the Interim Government of Iraq Dr. Ayad Allawi and United States Secretary of State Collin L. Powell to the President of the Council, ibid., Annex.

$61 R$ (on the Application of Al-Jedda) v. Secretary of State for Defence, UKHL (2007), supra u bilj. 58, paras. 23.-24.

62 Kod UN-run operacije Vijeće sigurnosti daje mandat Glavnom tajniku UN-a da uspostavi i vodi vojnu operaciju, bez obzira na pristanak vlade države u kojoj se operacija ima izvesti (ovdje je riječ o očuvanju mira od strane UN-a - UN peacekeeping). S druge strane, UNauthorized operacije su one kod kojih Vijeće sigurnosti ovlašćuje države članice ili regionalne organizacije na upotrebu svih potrebnih sredstava (uključujući i oružanu silu) radi održanja mira na određenom području, i u ovom slučaju neovisno o pristanku države o kojoj je riječ. UN-authorized operacije uglavnom se nazivaju peacemaking operations, dakle operacije za uspostavu mira. O razlikovanju spomenutih dviju vrsta operacija i ulozi UN-a u procesima održavanja, odnosno uspostave mira vidi u: Messineo, F., Things Could Only Get Better: Al-Jedda Beyond Behrami, Military Law and the Law of War Review, sv. 50, 2011., str. 326. et seq.

$63 R$ (on the Application of Al-Jedda) v. Secretary of State for Defence, UKHL (2007), supra u bilj. 58, para. 23.

64 Al-Jedda se obratio ESLJP-u jer je Dom lordova, unatoč utvrđenju da se protupravno pritvaranje ne može pripisati UN-u nego Ujedinjenoj Kraljevini, odbio njegovu žalbu uz obrazloženje da na temelju odredbe čl. 103. Povelje UN-a obveze država članica sadržane u rezoluciji Vijeća sigurnosti 1546 (2004) imaju prednost pred njihovim obvezama iz Europske konvencije te žalitelj nema pravo na zaštitu koju mu pruža odredba čl. 5. Europske konvencije. Vidi: ibid., paras. 150.-155. Opširniju kritiku odluke Doma lordova u slučaju Al-Jedda vidi u: Messineo, F., The House of Lords in Al-Jedda and Public International Law: Attribution of Conduct to UN-Authorized Forces and the Power of the Security Council to Displace Human Rights, Netherlands International Law Review, sv. 56, 2009., str. 43.-47.

65 Case of Al-Jedda v. The United Kingdom, Application No. 27021/08, Grand Chamber of the European Court of Human Rights, Judgement (2011), str. 49.-51., paras. 83.-86. 
bio pod isključivom kontrolom britanskih snaga, te je stoga tužitelj u potpunosti bio u vlasti i pod kontrolom Ujedinjene Kraljevine."66

Uzevši u obzir kritike na koje je naišla odluka u slučajevima Behrami i Saramati, začuđuje da u slučaju Al-Jedda ESLJP nije iskoristio priliku na autoritativan način zauzeti stav kojim bi potvrdio ili, pak, odbacio u prethodnoj presudi primijenjeni test vrhovne vlasti i kontrole. Napomenuvši samo da "Vijeće sigurnosti Ujedinjenih naroda nije provodilo niti efektivnu kontrolu niti vrhovnu vlast i kontrolu nad činima i propustima multinacionalnih snaga te se, stoga, pritvaranje tužitelja ne može pripisati Ujedinjenim narodima" ${ }^{67}$ te procjenjujući kontrolu Ujedinjene Kraljevine isključivo u kontekstu teritorijalne kontrole nad zatvorskim objektom i iračkim gradom Basrom, ${ }^{68}$ ESLJP se nije niti osvrnuo na komentar Komisije za međunarodno pravo u kontekstu pripisivosti u mirovnim operacijama. ${ }^{69}$ Ponovno pozivanje na vrhovnu vlast i kontrolu nasuprot efektivnoj kontroli prihvaćenoj i potvrđenoj od strane Komisije za međunarodno pravo, istovremeno ne pojašnjavajući njegov sadržaj i doseg, doprinosi jedino pravnoj nesigurnosti i neujednačenosti međunarodne sudske prakse.

Ipak, u presudi u slučaju Al-Jedda, unatoč spomenutim manjkavostima, ESLJP je ukazao i na neka pitanja koja su relevantna za promišljanje i utvrđivanje istovremene pripisivosti ponašanja dvama subjektima, a posljedično i za utvrđivanje zajedničke (ili podijeljene) odgovornosti za međunarodno protupravne čine počinjene u mirovnim operacijama. Naime, konstatacijom da: "Sud ne smatra da su davanjem ovlasti temeljem rezolucije 1511 djela pripadnika multinacionalnih snaga postala pripisiva Ujedinjenim narodima niti, što je još važnije, u svrhu ovog slučaja, prestala biti pripisiva državama koje su svoje oružane snage stavile na raspolaganje (...)"70 Sud je implicite priznao mogućnost podjele odgovornosti država i UN-a za kršenja međunarodnog prava počinjena od strane pripadnika tih misija. ${ }^{71}$ Šteta je što ESLJP nije detaljnije problematizirao ovo pitanje i uvjerljivijim argumentima podržao stajalište Komisije za međunarodno pravo da pripisivost nekog ponašanja međunarodnoj organizaciji ne znači da se isto ponašanje ne može pripisati i državi, i obrnuto. ${ }^{72}$

\subsection{PRAKSA NEKIH NACIONALNIH SUDOVA}

Pitanje kontrole radi utvrđenja pripisivosti ponašanja državi odnosno međunarodnoj organizaciji raspravljalo se i pred nekim nacionalnim sudovima, čije je odluke svakako važno raz-

66 Ibid.

67 Ibid., str. 50., para. 84 .

68 Ibid., 50.-51., para. 85.

69 Komisija je, naime, istaknula da pitanje pripisivosti ponašanja organa ili agenta neke države ili međunarodne organizacije ustupljenog drugoj međunarodnoj organizaciji, posebno u kontekstu mirovnih operacija UN-a, ovisi upravo o de facto kontroli nad konkretnim ponašanjem. Vidi Second Report of the International Law Commission (2004), supra u bilj. 40, str. 50.-51., paras. 3., 7.-8. Al-Jedda v. The United Kingdom, ECtHR (2011), supra u bilj. 65, str. 48.-49., para. 80.

72 Komentar Nacrta 2011, supra u bilj. 5, str. 16., para. 4. Komisija je naglasila da je razumljivo da radi učinkovitosti vojnih operacija UN nastoji zadržati isključivo zapovjedništvo i kontrolu nad mirovnim snagama, ali da se, međutim, pitanje pripisivosti ponašanja, s obzirom na stupanj kontrole koju de facto provodi UN s jedne te država s druge strane, mora razmatrati prema kriteriju utvrđenih činjenica. Ibid., str. 23., para. 9. 
motriti u kontekstu usporedbe s prethodno analiziranim odlukama ESLJP-a i radom Komisije za međunarodno pravo o odgovornosti država i međunarodnih organizacija.

\subsubsection{PRAKSA NIZOZEMSKIH SUDOVA}

Jedna od zasigurno najrelevantnijih presuda koja se dotiče teme ovoga rada je presuda nizozemskog suda prvog stupnja (a vidjet ćemo infra i presuda donesena po žalbenom postupku) u slučaju N. H. protiv Nizozemske. ${ }^{73} \mathrm{U}$ toj se odluci razmatralo pitanje odgovornosti Nizozemske za djelovanje nizozemskog vojnog kontingenta u Srebrenici (the Dutch battalion - Dutchbat), koji je bio angažiran kao dio UN-ovih mirovnih snaga UNPROFOR radi zaštite sigurne zone uspostavljene na tom području. Zbog brojnih propusta nizozemskog kontingenta, među ostalim i zbog odluke nizozemskih zapovjednika da se ne evakuiraju bosanski muslimani zajedno s ostatkom bataljuna nego su ostavljeni nezaštićeni, brojni muslimani odvedeni su od strane pripadnika vojske bosanskih Srba i paravojnih skupina te poubijani u srpnju 1995. godine. ${ }^{74}$

Prihvativši argumente Nizozemske sud prvog stupnja je zaključio da su navedena protupravna djela pripisiva UN-u a ne Nizozemskoj, uz obrazloženje da su pripadnici nizozemskog bataljuna Dutchbat djelovali pod operativnim zapovjedništvom i kontrolom UN-a (operational command and control), a na temelju rezolucije Vijeća sigurnosti 819 (1993) iz glave VII. Povelje UN-a. ${ }^{75}$ Iako se nizozemski sud nije izričito pozvao na test vrhovne vlasti i kontrole sukladno praksi ESLJP-a, jasno je, budući da je isključivo ispitivao zapovjednu strukturu UN-a te izričito naveo da je poštovanje te strukture temelj pripisivosti protupravnog ponašanja $\mathrm{UN}-\mathrm{u},{ }^{76} \mathrm{da}$ je primijenio upravo test iz odluke u slučajevima Behrami i Saramati. Pogriješio je prvostupanjski sud Nizozemske kad je odbacio navode tužitelja da je unutar nizozemskog bataljuna bilo ozbiljnih propusta i nedovoljno nadzora nad poštovanjem temeljnih standarda postupanja (a što bi, prema tužitelju, bilo pripisivo Nizozemskoj) i sve moguće propuste isključivo pripisao UN-u, odbacivši mogućnost istovremene pripisivosti, uz obrazloženje da se nitko od stranaka u postupku na to nije pozvao. ${ }^{77}$

Žalbeni je sud Nizozemske, međutim, zaključio da je, što se tiče pitanja pripisivosti u mirovnim operacijama UN-a, ispravno primijeniti test efektivne kontrole nad konkretnim ponašanjem, koji je prihvaćen ne samo u Komisiji za međunarodno pravo, nego općenito i u međunarodnopravnoj teoriji ${ }^{78}$ Osim što je navedeno da je potrebno ispitati sve okolnosti slučaja, značajno je da je Sud uveo, čini nam se, novo, prošireno tumačenje standarda efektivne kontrole. Konkretno, navedeno je da je u slučaju da se utvrdi da nisu dane specifične instrukcije glede počinjenja nekog čina, potrebno odgovoriti na pitanje jesu li UN ili država imali ovlasti

73 N. H. v. The State of the Netherlands, LJN: BF0181, Rechtbank's-Gravenhage, 265615/HA ZA 06-1671 (2008).

74 O slučaju N. H. protiv Nizozemske detaljnije vidi Buchan, op. cit. u bilj. 48, str. 294.; Boon, op. cit. u bilj. 29, str. 358.

75 N. H. v. The State of the Netherlands (2008), supra u bilj. 73, paras. 4.9., 4.14., 4.15.; UN Security Council Resolution, UN Doc. S/ RES/819 (1993) u vezi s UN Doc. S/RES/815 (1993).

76 Nizozemski je sud izričito naveo da bi o pripisivosti ponašanja Dutchbata Nizozemskoj moglo govoriti jedino u slučaju da se utvrdi da su pripadnici Dutchbata postupali protivno UN-ovim naredbama i djelovali sukladno instrukcijama upućenima od strane Nizozemske. Vidi N. H. v. The State of the Netherlands (2008), supra u bilj. 73, para. 4.14.1. 
da spriječe konkretno protupravno ponašanje. ${ }^{79} \mathrm{U}$ postupku je utvrđeno da je Nizozemska (nizozemski bataljun) bila u mogućnosti spriječiti odvođenje muslimanskih žrtava te je Sud na tom temelju utvrdio njezinu međunarodnu odgovornost..$^{80}$

Osim toga, značajno je da je Žalbeni sud Nizozemske kao polaznu točku svojeg odlučivanja zauzeo stajalište da primjena testa efektivne kontrole može rezultirati pripisivošću protupravnog ponašanja ne samo državi, nego i UN-u.$^{81}$ Dakle, ne samo da je ovaj sud odbacio standard vrhovne vlasti i kontrole iz prakse ESLJP-a, nego je ostavio otvorenom mogućnost dvostruke pa i višestruke pripisivosti, što bi odgovaralo i stajalištu Komisije za međunarodno pravo. ${ }^{82}$

Podržavši odluku suda drugog stupnja u slučaju Nuhanovičs3 što se tiče moguće dvostruke pripisivosti, Vrhovni je sud Nizozemske otvorio put razvoju običajnog prava o odgovornosti za međunarodno protupravne čine počinjene u mirovnim operacijama, a u smislu odredbe čl. 7. Nacrta 2011 Komisije za međunarodno pravo. ${ }^{84}$ Potvrđeno je da je relevantan faktor pripisivosti stvarna (factual) kontrola nad konkretnim ponašanjem te da je potrebno uzeti u obzir sve činjenične okolnosti i specifičan kontekst konkretnog slučaja. ${ }^{85}$ Osim toga, što je još važnije, time su poboljšane mogućnosti žrtava takvih protupravnih čina da traže i realiziraju zahtjeve za naknadom štete zbog počinjenih povreda njihovih prava.

\subsubsection{PRAKSA BELGIJSKIH SUDOVA}

I neki drugi sudovi imali su prilike raspravljati o problematici pripisivosti ponašanja pripadnika mirovnih operacija pod okriljem UN-a koji su, uz tragične posljedice, propustili priliku spriječiti neka od najtežih kršenja prava čovjeka (ubojstva, teške tjelesne ozljede) počinjena u okolnostima u kojima je osnovni zadatak bio osigurati upravo mir ili barem stabilizirati napetosti izazvane sukobima određenih skupima u nekim državama. Osim u Srebrenici u BiH, i u Ruandi su se dogodili tragični događaji koji su doveli u pitanje učinkovitost mirovnih operacija uopće.

Tako je prvostupanjski sud Belgije u slučaju Mukeshimana-Ngulinzira protiv Belgije odlučivao o odgovornosti za napuštanje de facto izbjegličkog kampa u kojem je utočište pronašlo oko 2.000 pripadnika etničke skupine Tutsi u Kigaliju, u Ruandi u travnju 1994. godine, nakon čega su pripadnici etničke skupine Hutu zapucali na kamp i bacili granate, a skupina Intera-

79 Ibid., para. 5.9.

$80 \quad$ Ibid., paras. 5.18., 5.20 .

81 Ibid., para. 5.9 .

82 Žalbeni sud Nizozemske donio je identičnu presudu i u slučaju Mustafić-Mujić et al. v. The State of The Netherlands, The Court of Appeal of The Hague, Case No. 200.020.173/01 (2011).

83 Vidi The State of the Netherlands (Ministry of Defence and Ministry of Foreign Affairs) v. Hasan Nuhanović, Supreme Court of the Netherlands, Judgement, No. 12/03324 (2013).

84 Bakker, Ch., Dual Attribution of Acts Committed by a UN Peacekeeping Force: An Emerging Norm of Customary International Law? The Dutch Supreme Court's Judgements in Nuhanović and Mustafić, Italian Yearbook of International Law, sv. 23, 2013., str. 287. et seq. Vidi i The State of the Netherlands v. Nuhanović (2013), supra u bilj. 83, str. 22.-23., para. 3.11.2. Vrhovni sud u presudi povezuje odredbu čl. 7. i čl. 48. st. 1. Nacrta članaka o odgovornosti međunarodnih organizacija, u kojem se govori o istovremenoj odgovornosti države i međunarodne organizacije za isti protupravni čin, odnosno o pravu pozivanja na odgovornost svakog od ta dva subjekta. Vidi ibid. 
hamwe mačetama i bajunetima izmasakrirala je Tutsije u kampu. ${ }^{86} \mathrm{U}$ toj je presudi utvrđeno da je odluka zapovjednika belgijskog kontingenta UN-ovih snaga UNAMIR u Ruandi (United Nations Assistance Mission for Rwanda) o napuštanju kampa donesena pod kontrolom belgijske vlade, a ne UNAMIR-a. ${ }^{87}$ Obrazloženo je da iako su belgijske snage bile dijelom mirovne operacije UN-a, one su ostale pod zapovjedništvom i kontrolom Belgije koja je i dala naredbu o evakuaciji belgijskog kontingenta iz kampa.

Ono što je za naše istraživanje relevantno jest konstatacija suda da UN nije provodio efektivnu kontrolu nad postupanjem belgijskih snaga, što je, posljedično, usmjerilo belgijski sud da primijeni pravila o odgovornosti država za međunarodno protupravne čine (u ovom slučaju Belgije). ${ }^{88} \mathrm{U}$ spomenutoj je presudi belgijski sud prvog stupnja istaknuo operativni karakter efektivne kontrole i potvrdio da u stvarnosti, u tijeku mirovne operacije, a zbog kaotičnih okolnosti na terenu i teškoća u komunikaciji, efektivno zapovjedništvo i kontrola UN-a mogu biti preneseni na državu čiji su kontingenti na terenu pa se onda odlučuje o odgovornosti te države. ${ }^{89}$

Standard efektivne kontrole, prema našem mišljenju, u prvostupanjskoj presudi u slučaju Mukeshimana-Ngulinzira protiv Belgije najjasnije je od svih prije analiziranih presuda obrazložio sadržaj i smisao standarda efektivne kontrole i potvrdio da kad se govori o pripisivosti čina pripadnika mirovnih operacija UN-u ili državama koje svoje kontingente stavljaju na raspolaganje za konkretnu operaciju, vrhovna kontrola i zapovjedništvo ne mogu biti relevantan čimbenik prema kojem se odlučuje o pripisivosti određenog ponašanja i eventualnoj odgovornosti. Sukladno većini dosadašnjih sudskih odluka, a i razmatranjima Komisije za međunarodno pravo, presudna je faktična, stvarna kontrola koja se provodi nad konkretnim ponašanjem tijekom počinjenja protupravnog čina, dakle, uz uvažavanje svih utvrđenih okolnosti danog slučaja. ${ }^{90}$ Formalna struktura pojedine operacije i ugovori o detaljima operacije mogu služiti kao usmjerenje i dati uvid u sastav i funkcioniranje zapovjednog lanca unutar mirovnih operacija UN-a, ali ne mogu odgovoriti na pitanje o stvarnoj (faktičnoj), operativnoj kontroli koja se provodi u tijeku same operacije.

\subsubsection{PRAKSA SUDOVA UJEDINJENE KRALJEVINE}

Visoki i Žalbeni sud Ujedinjene Kraljevine 2014. i 2015. godine raspravljali su o zahtjevu afganistanskog državljanina Serdara Mohammeda za utvrđenjem odgovornosti za njegovo protupravno zadržavanje u pritvoru od strane britanskih oružanih snaga 2010., a koje su u Afganistanu djelovale kao dio ISAF-a (International Security Assistance Force), operacije sastavljene od multinacionalnih snaga odobrene rezolucijom Vijeća sigurnosti UN-a 1386 (2001) na temelju glave VII. Povelje UN-a. Cilj angažiranja ISAF-a bio je pružiti pomoć privremenoj vladi

86 Ukratko o događaju vidi Janik, R., International Responsibility, u: Nollkaemper, A. et al. (ur.), International Law in Domestic Courts: A Casebook, Oxford University Press, Oxford, 2018., str. 402.-403.

87 Komentar Nacrta 2011, supra u bilj. 5, str. 22., para. 8.

88 Janik, op. cit. u bilj. 86, str. 402.

89 Vidi Ryngaert, C., Apportioning Responsibility between the UN and Member State in UN Peace-Support Operations: An Inquiry Into the Application of 'Effective Control' Standard After Behrami, Israel Law Review, sv. 45, 2012., str. 176.-177. 
u Afganistanu (Afghan Interim Authority) u održavanju sigurnosti u Kabulu i okolnom području. ${ }^{91}$ Tužitelj je tvrdio da je pritvaranje (zbog sumnje da je bio talibanski zapovjednik) iznad vremenske granice od dopuštenih 96 sati bilo protivno zakonu Human Rights Act (1998.) i zakonima Afganistana. $^{92}$

Prvostupanjski je sud odlučivao o pripisivosti odluke o pritvaranju i odgovornosti za prolongirano pritvaranje traženjem odgovora na dva pitanja: prvo, jesu li aktivnosti ISAF-a u Afganistanu pripisive UN-u i drugo, je li za pritvaranje odgovoran ISAF, Ujedinjena Kraljevina ili oboje. ${ }^{93}$ Pozivajući se na prasku ESLJP-a (odluka u slučajevima Behrami i Saramati te Al-Jedda), Visoki je sud zaključio da je Vijeće sigurnosti imalo efektivnu kontrolu (vrhovnu vlast i kontrolu) nad ISAF-om, što upućuje na zaključak da su djelovanja ISAF-a pripisiva Vijeću sigurnosti, odnosno UN-u. ${ }^{94}$ Ovdje se sud pozvao na sudsku praksu ESLJP-a bez valjane i jasne argumentacije o ispravnosti takvog postupanja, i ponovno, bez jasnog definiranja sadržaja efektivne kontrole (kao i vrhovne vlasti i kontrole). ${ }^{95}$ Ono što doprinosi još većoj konfuziji u primjeni pravila o pripisivosti jest daljnje rezoniranje Visokog suda koji utvrđuje da je Ujedinjena Kraljevina provodila vlastitu, zasebnu politiku o zadržavanju pritvorenika, da je Mohammed bio zadržan u pritvoru u vojnoj bazi Camp Bastion pod de facto kontrolom britanskih snaga, te da iz navedenih činjenica slijedi jasan zaključak da se pritvaranje Serdara Mohammeda može pripisati jedino Ujedinjenoj Kraljevini. ${ }^{96} \mathrm{U}$ drugostupanjskom postupku Žalbeni je sud, uz neke modifikacije argumenata, došao do istog rezultata i pripisao čin zadržavanja Mohammeda u pritvoru isključivo Ujedinjenoj Kraljevini. ${ }^{97}$

\section{ZAKLJUČAK - POUKE IZ SUDSKE PRAKSE I SMJERNICE ZA TUMAČENJE I PRIMJENU STANDARDA EFEKTIVNE KONTROLE}

Oskudnost dosadašnje sudske prakse relevantne za utvrđivanje odgovornosti država odnosno međunarodnih organizacija u mirovnim operacijama (obično pod okriljem UN-a), uz istovremeno šturo i nedostatno tumačenje dosega primjene odredbe čl. 7. Nacrta 2011 Komisije za međunarodno pravo, teško da može služiti donošenju jasnih i u svakoj situaciji primjenjivih pravila o pripisivosti ponašanja sudionika mirovnih operacija koji su ustupljeni nekoj međunarodnoj organizaciji. Analiza odluka donesenih u praksi ESLJP-a te nekoliko presuda državnih sudova Nizozemske, Belgije i Ujedinjene Kraljevine pokazala je da upravo zbog

91 UN Security Council Resolution, UN Doc. S/RES/1386 (2001), para. 1.

92 Serdar Mohammed v. Ministry of Defence and Mohammed Qasim et al. v. Secretary of State for Defence, High Court of Justice, No. [2014] EWHC 1369 (QB), str. 1., paras. 1.-5. Mohammeda su britanske snage ISAF-a držale u pritvoru od 7. travnja do 25. srpnja 2010. godine.

93 Ibid., str. 51., para. 170.

94 Ibid., str. 51.-53., paras. 171.-178.

95 Rylatt, J. W., Attribution of Conduct in UN-Authorised International Military Operations: Serdar Mohammed beofre the Courts of England and Wales, Military Law and the Law of War Review, sv. 55, 2016., str. 100.-101.

96 Sud je isključio raspravu o zajedničkoj odgovornosti s obzirom na zaključak da se pritvaranje ne može pripisati ni ISAF-u ni UN-u. Vidi Serdar Mohammed v. Ministry of Defence (2014), supra u bilj. 92, str. 53.-55., paras. 180.-187.

97 Serdar Mohammed and Others v. Secretary of State for Defence; Yunus Rahmatullah and the Iraqi Civilian Claimants v. Ministry of Defence and Foreign and Commonwealth Office, Court of Appeal (Civil Division), No. [2015] EWCA Civ 843. 
nedovoljne preciznosti formulacije čl. 7., nedorečenosti komentara Komisije za međunarodno pravo, ali ponajviše zbog složenosti i raznolikosti strukture, djelovanja i ciljeva mirovnih operacija koje se uspostavljaju u današnje vrijeme vrlo teško pronaći i primijeniti odgovarajuću metodologiju odlučivanja. ${ }^{98}$ To, naravno, rezultira nesigurnošću u primjeni pravila o pripisivosti u kontekstu mirovnih operacija, usporava stvaranje običajnopravnih pravila o toj materiji i u konačnici, i možda najvažnije, ne pruža žrtvama teških kršenja međunarodnoga prava adekvatnu i dostupnu pravnu zaštitu.

Rezultati analize znanstvenih radova o primjeni odredbe o pripisivosti ponašanja organa države ustupljenih za potrebe mirovne operacije pod vodstvom neke međunarodne organizacije, s jedne strane te dostupna sudske praksa, s druge, pokazuju nam da je radi postizanja konzistentnosti u primjeni relevantnih pravila o pripisivosti i postizanja što veće mjere pravne sigurnosti nužno definirati sljedeće elemente pripisivosti. Prije svega, potrebno je točno definirati pojam stavljanja na raspolaganje državnih organa nekoj međunarodnoj organizaciji. Naime, točno određenje toga pojma predstavlja prvi korak u postupanju suda, odnosno u odlučivanju treba li se u konkretnom slučaju uopće primijeniti odredba čl. 7. Nacrta 2011, ili su, pak, primjenjiva pravila o odgovornosti država. Dakle, ako se, uzimajući u obzir sve okolnosti slučaja, ustanovi da UN ima samo nadzornu ulogu, a da pitanja operativnog djelovanja, odnosno donošenja odluka o postupanju tijekom operacije ostaju u nadležnosti države ili država koje ustupaju svoje kontingente, jasno je da će se primijeniti pravila o pripisivosti ponašanja državi na temelju Nacrta 2001. ${ }^{99}$

U drugim slučajevima, u kojima UN preuzima veću ulogu u odlučivanju na terenu, potrebno je radi utvrđivanja pripisivosti za čine počinjene tijekom mirovne operacije ocijeniti koji od involviranih subjekata je provodio efektivnu kontrolu nad konkretnim činom. Pritom je, prema našem mišljenju, ključno voditi se tumačenjem efektivne kontrole koje je navela Komisija za međunarodno pravo, pa makar bilo i nedovoljno obrazloženo, i dati mu konkretnu potvrdu u praksi. Smatramo, naime, da institut efektivne kontrole u međunarodnom pravu već ima određeno značenje i da ga, pogotovo nakon donošenja Nacrta 2001 o odgovornosti država i potvrde da standard efektivne kontrole već ima običajnopravni status, ${ }^{100}$ Komisija za međunarodno pravo u Nacrtu 2011 o odgovornosti međunarodnih organizacija nije ni namjeravala primijeniti u nekom drugom, potpuno različitom smislu, nego uzimajući u obzir specifične okolnosti u kojima države i međunarodne organizacije surađuju radi postizanja ciljeva mirovnih operacija.

Slijedom toga, predlažemo sljedeće smjernice u ispravnom tumačenju sadržaja efektivne kontrole kojim se sudovi i druga tijela koja odlučuju o pripisivosti čina počinjenih u kontekstu mirovnih operacija trebaju voditi: efektivna kontrola je standard prema kojem su isključivo

98 Dannenbaum razlikuje sljedeće oblike suradnje između država i međunarodnih organizacija radi suzbijanja prijetnje međunarodnom miru i sigurnosti: ad hoc koalicije, razmještanje vojnika pod vodstvom međunarodne organizacije, mirovne operacije, multinacionalne okupacijske snage i vojne operacije integrirane u međunarodnu upravu na određenom području. Detaljnije vidi u: Dannenbaum, T., Dual Attribution in the Context of Military Operations, International Organizations Law Review, sv. 12, 2015., str. 402. 
relevantne konkretne činjenice i okolnosti u kojima je neko djelo počinjeno; ${ }^{101}$ efektivna kontrola treba se tumačiti u smislu operativne kontrole (operational control), a ne kao vrhovna kontrola (ultimate control); ${ }^{102}$ formalna obilježja djelovanja same operacije relevantne su za druga pitanja (poput pravnog temelja osnivanja i angažiranja operacije, sastava i brojnosti sudionika operacije, zapovjedne strukture i alokacije funkcija u okviru operacije), dok se za pripisivost konkretnog čina počinjenog tijekom mirovne operacije traži kontrola upravo nad tim konkretnim događajem (primjerice, davanje naredbe za počinjenje čina ili naloga za određeno postupanje tijekom kojeg je počinjen ili koji je omogućio počinjenje toga čina, osobito u slučaju kad se zaobilazi zapovjedna struktura UN-a). ${ }^{103}$

Jasno je da kod međunarodne suradnje između država i međunarodnih organizacija u pogledu sudjelovanja u operacijama radi osiguranja međunarodnog mira i sigurnosti dolazi do međusobnog ustupanja i preuzimanja nekog oblika kontrole nad pojedinim aspektima operacija, a sve radi njihove što veće učinkovitosti. ${ }^{104}$ Zbog toga odgovor na pitanje o pripisivosti određenih čina i propusta počinjenih tijekom mirovnih operacija nije jednostavan, ni uvijek očit. Međutim, s obzirom na manjkavosti dosad donesenih odluka pred međunarodnim i pojedinim državnim sudovima, nadamo se da će se sudovi u nekim budućim slučajevima voditi prije svega teorijskim rješenjima koje je ponudila Komisija za međunarodno pravo, a onda i pozitivnim primjerima iz sudske prakse koji su pripisivost utemeljili isključivo u stvarnoj (faktičnoj) kontroli koju je određeni subjekt provodio nad konkretnim događajem. A s obzirom na to da država koja ustupa svoje vojne kontingente obično zadržava određene ovlasti nad svojim organima, a istovremeno predaje određenu kontrolu međunarodnoj organizaciji, sudovi bi trebali biti otvoreniji prema ispitivanju moguće dvostruke (ili višestruke) pripisivosti, a ovisno o konkretnim okolnostima, i prema utvrđivanju zajedničke (ili podijeljene) međunarodne odgovornosti.

Najvažniji učinci predloženih rješenja bili bi sljedeći: prije svega, izbjegle bi se situacije u kojima bi sudovi, poput ESLJP-a, zbog nepostojanja nadležnosti ratione personae bili onemogućeni u daljnjem odlučivanju, a tužitelji (žrtve počinjenih protupravnih čina i članovi njihovih obitelji) ostali bez odgovarajuće pravne zaštite. Ne smije se zaboraviti na jedno od temeljnih pravnih načela o odgovornosti, a to je da iz protupravnog čina nastaje poseban pravni odnos između povreditelja i povrijeđenoga, a on se očituje u dužnosti povreditelja da ukloni posljedice svog protupravnog čina. ${ }^{105} \mathrm{~S}$ druge strane, odredba čl. 7. Nacrta 2011 dobila bi svoj

101 Komisija priznaje da je razumljivo da UN inzistira na tome da ta organizacija ima isključivo zapovjedništvo i kontrolu nad mirovnim operacijama radi njihove učinkovitosti, međutim naglašava da se pitanje pripisivosti treba temeljiti na činjeničnom kriteriju. Vidi Komentar Nacrta 2011, supra u bilj. 5, str. 23., para. 9. Također vidi i komentar Ujedinjene Kraljevine spomenute u izvješću specijalnog izvjestitelja Gaje prema kojem odgovor na pitanje gdje leži efektivna kontrola u mirovnim operacijama ovisi o svim činjeničnim okolnostima i kontekstu u kojem je djelovala međunarodna organizacija i njezini članovi. Vidi Eighth Report on the Responsibility of International Organizations by Giorgio Gaja, Special Rapporteur, International Law Commission, Sixty-third Session, UN Doc. A/CN.4/640 (2011), str. 13., para. 34.

102 Kao što je to pogrešno zaključio ESLJP u odluci u slučajevima Behrami i Saramati. Vidi supra u poglavlju 3.1. Vidi i Rao, op. cit. u bilj. 4, str. 409.

103 Kao, primjerice, u slučaju Nuhanović protiv Nizozemske ili Mukeshimana-Ngulinzira protiv Belgije. Vidi supra u poglavljima 3.3.1. i 3.3.2. Slično i Salerno, F., International Responsibility for the Conduct of 'Blue Helmets': Exploring the Organic Link, u: Ragazzi, op. cit. u bilj. 4, str. 424.-427.

104 Dannenbaum, op. cit. u bilj. 100, str. 412.

105 Andrassy, J.; Bakotić, B.; Seršić, M.; Vukas, B., Međunarodno pravo, sv. 3, Školska knjiga, Zagreb, 2006., str. 114. et seq. "Whenever a duty established by any rule of international law has been breached by an act or an ommission, a new legal relationship automatically comes into existence. This relationship is established between the subject to which the act is imputable, who must 
praktični smisao i omogućila dosljedniju primjenu pravila o pripisivosti utemeljenu u efektivnoj kontroli u mirovnim operacijama, što bi, pak, moglo imati pozitivan utjecaj na stvaranje međunarodnog običajnog prava. Ne smijemo podcijeniti ni preventivni učinak koji bi buduće odluke mogle imati na ponašanje pripadnika mirovnih misija i na jačanje njihove svijesti o odgovornosti koju imaju u ispunjavanju humanitarnih ciljeva uspostavljanja mira i obrane temeljnih načela međunarodnog prava.

\section{LITERATURA}

1. Amrallah, B., The International Responsibility of the United Nations for Activities Carried Out by U.N. Peace-keeping Forces, Révue Egyptienne de Droit International, sv. 32, 1976., str. 57.-82.

2. Andrassy, J.; Bakotić, B.; Seršić, M.; Vukas, B., Međunarodno pravo, sv. 3, Školska knjiga, Zagreb, 2006.

3. Bakker, Ch., Dual Attribution of Acts Committed by a UN Peacekeeping Force: An Emerging Norm of Customary International Law? The Dutch Supreme Court's Judgements in Nuhanović and Mustafić, Italian Yearbook of International Law, sv. 23, 2013., str. 287.-297.

4. Bell, C. A., Reassessing Multiple Attribution: the International Law Commission and the Behrami and Saramati Decision, N.Y.U. Journal of International Law and Politics, sv. 42, 2009./2010., str. 501.-548.

5. Boon, K. E., Are Control Tests Fit for the Future? The Slippage Problem in Attribution Doctrines, Melbourne Journal of International Law, sv. 15, 2014., str. 330.-377.

6. Buchan, R., UN Peacekeeping Operations: When Can Unlawful Acts Committed by Peacekeeping Forces Be Attributed to the UN?, Legal Studies, sv. 32, 2012., str. 282.-301.

7. Canto Lopez, M., Towards Dual or Multiple Attribution: the Strasbourg Court and the Liability of Contracting Parties' Troops Contributed to the United Nations, International Organizations Law Review, sv. 10, 2013., str. 193.-222.

8. Cassese, A., The Nicaragua and Tadić Tests Revisited in Light of the ICJ Judgement on Genocide in Bosnia, European Journal of International Law, sv. 18, 2007., str. 649.-668.

9. Dannenbaum, T., Dual Attribution in the Context of Military Operations, International Organizations Law Review, sv. 12, 2015., str. 401.-426.

10. Dannenbaum, T., Translating the Standard of Effective Control into a System of Effective Accountability: How Liability Should be Apportioned for Vioaltions of Human Rights by Member State Troop Contingents Serving as United Nations Peacekeepers, Harvard International Law Journal, sv. 51, 2010., str. 113.-192.

11. Gal-Or, N., Ryngaert, C., From Theory to Practice: Exploring the Relevance of the Draft Articles on the Responsibility of International Organizations (DARIO) - The Responsibility of the WTO and the UN, German Law Journal, sv. 13, 2012., str. 511.-541.

12. Janik, R., International Responsibility, u: Nollkaemper, A. et al. (ur.), International Law in Domestic Courts: A Casebook, Oxford University Press, Oxford, 2018.

13. Lapaš, D., Šošić, T. M., Međunarodno javno pravo - izbor dokumenata, Sveučilište u Zagrebu, Pravni fakultet, Zagreb, 2005.

'respond' by making adequate reparation, and the subject who has a claim to reparation because of the breach of duty." Vidi u: Amrallah, B., The International Responsibility of the United Nations for Activities Carried Out by U.N. Peace-keeping Forces, Révue Egyptienne de Droit International, sv. 32, 1976., str. 70. 
14. Leck, Ch., International Responsibility in United Nations Peacekeeping Operations: Command and Control Arrangements and the Attribution of Conduct, Melbourne Journal of International Law, sv. 10, 2009., str. 346.-364.

15. Messineo, F., The House of Lords in Al-Jedda and Public International Law: Attribution of Conduct to UN-Authorized Forces and the Power of the Security Council to Displace Human Rights, Netherlands International Law Review, sv. 56, 2009., str. 35.-62.

16. Messineo, F., Things Could Only Get Better: Al-Jedda Beyond Behrami, Military Law and the Law of War Review, sv. 50, 2011., str. 321.-346.

17. Milanović, M., State Responsibility for Genocide, European Journal of International Law, sv. 17, 2006., str. 553.-604.

18. Montejo, B., The Notion of 'Effective Control'under the Articles on the Responsibility of International Organizations, u: Ragazzi, M. (ur.), Responsibility of International Orgnizations: Essays in Memory of Sir Ian Brownlie, Martinus Nijhoff Publishers, Leiden/Boston, 2013., str. 389.-404.

19. Mujezinović Larsen, K., 'Neither Effective Control nor Ultimate Authority and Control': Attribution of Conduct in Al-Jedda, Military Law and the Law of War Review, sv. 50, 2011., str. 347.-368.

20. Rao, P. S., United Nations Responsibility from Authorizing the Use of Force, u: Ragazzi, M. (ur.), Responsibility of International Orgnizations: Essays in Memory of Sir Ian Brownlie, Martinus Nijhoff Publishers, Leiden/Boston, 2013., str. 405.-414.

21. Rylatt, J. W., Attribution of Conduct in UN-Authorised International Military Operations: Serdar Mohammed beofre the Courts of England and Wales, Military Law and the Law of War Review, sv. 55, 2016., str. 75.-115.

22. Ryngaert, C., Apportioning Responsibility between the UN and Member State in UN Peace-Support Operations: An Inquiry Into the Application of 'Effective Control' Standard After Behrami, Israel Law Review, sv. 45, 2012., str. 151.-178.

23. Salerno, F., International Responsibility for the Conduct of 'Blue Helmets': Exploring the Organic Link, u: Ragazzi, M. (ur.), Responsibility of International Orgnizations: Essays in Memory of Sir Ian Brownlie, Martinus Nijhoff Publishers, Leiden/Boston, 2013., str. 415.-427.

24. Sari, A., Jurisdiction and International Responsibility in Peace Support Operations: the Behrami and Saramati Cases, Human Rights Law Review, sv. 8, 2008., str. 151.-170.

25. Shraga, D., ILC Articles on Responsibility of International Organizations: The Interplay between the Practice and the Rule (a View from the United Nations), u: Ragazzi, M. (ur.), Responsibility of International Orgnizations: Essays in Memory of Sir Ian Brownlie, Martinus Nijhoff Publishers, Leiden/Boston, 2013., str. 201.-210.

26. Uddin, Md. K., Human Rights Violations by UN Peacekeepers: An End to Impunity, Security and Human Rights, sv. 25, 2014., str. 130.-144.

\section{SUDSKA PRAKSA}

1. Banković and Others v. Belgium and Others, Application No. 52207/99, Grand Chamber of the European Court of Human Rights, Decision as to the Admissibility (2001).

2. Behrami v. France, Application No. 71412/01 and Saramati v. France, Germany and Norway, Application No. 78166/01, Grand Chamber of the European Court of Human Rights, Decision as to the Admissibility (2007).

3. Berić and Others v. Bosnia and Herzegovina, Applications Nos. 36357/04, 36360/04, 38346/04, 41705/04, 45190/04, 45578/04, 45579/04, 45580/04, 91/05, 97/05, 100/05, 101/05, 1121/05, 1123/05, 1125/05, 
$1129 / 05,1132 / 05,1133 / 05,1169 / 05,1172 / 05,1175 / 05,1177 / 05,1180 / 05,1185 / 05,20793 / 05$ and 25496/05, European Court of Human Rights, Decision as to the Admissibility (2007).

4. Gajić v. Germany, Application No. 31446/02, European Court of Human Rights, Decision as to the Admissibility (2007).

5. Case of Ilascu and Others v. Moldova and Russia, Application No. 48787/99, European Court of Human Rights, Judgement (2004).

6. Case of Issa and Others v. Turkey, Application No. 31821/96, European Court of Human Rights, Judgement (2004).

7. Kasumaj v. Greece, Application No. 6974/05, European Court of Human Rights, Decision as to the Admissibility (2007).

8. Case of Al-Jedda v. The United Kingdom, Application No. 27021/08, Grand Chamber of the European Court of Human Rights, Judgement (2011).

9. R (on the Application of Al-Jedda) v. Secretary of State for Defence (2007), UKHL, 58.

10. N. H. v. The State of the Netherlands, LJN: BF0181, Rechtbank's-Gravenhage, 265615/HA ZA 061671 (2008).

11. Mustafic-Mujić et al. v. The State of The Netherlands, The Court of Appeal of The Hague, Case No. 200.020.173/01 (2011).

12. Nuhanović v. The State of The Netherlands, The Court of Appeal of The Hague, Case No. 200.020.174/01 (2011).

13. The State of the Netherlands (Ministry of Defence and Ministry of Foreign Affairs) v. Hasan Nuhanovic, Supreme Court of the Netherlands, Judgement, No. 12/03324 (2013).

14. Serdar Mohammed v. Ministry of Defence and Mohammed Qasim et al. v. Secretary of State for Defence, High Court of Justice, No. [2014] EWHC 1369 (QB).

15. Serdar Mohammed and Others v. Secretary of State for Defence; Yunus Rahmatullah and the Iraqi Civilian Claimants v. Ministry of Defence and Foreign and Commonwealth Office, Court of Appeal (Civil Division), No. [2015] EWCA Civ 843.

16. Military and Paramilitary Activities in and against Nicaragua (Nicaragua v United States of America), Merits, Judgement, ICJ Reports (1986), str. 14.

17. Case Concerning Application of the Convention on the Prevention and Punishment of the Crime of Genocide (Bosnia and Herzegovina v. Serbia and Montenegro), Judgement, ICJ Reports (2007), str. 43.

18. Case Concerning the Application of the Convention on the Prevention and Punishment of the Crime of Genocide (Croatia v. Serbia), Judgement, ICJ Reports (2015), str. 3.

19. Prosecutor v. Duško Tadić, Appeals Chamber Judgement, Case No. IT-94-1-A (1999).

\section{AKTI UJEDINJENIH NARODA}

1. Draft Articles on Responsibility of States for Internationally Wrongful Acts, with Commentaries, 2001, Report of the International Law Commission on the Work of Its Fifty-third Session (A/56/10), YILC (2001), sv. II, Part Two.

2. Report of the International Law Commission on the Work of Its Fifty-sixth Session, General Assembly Official Records, Supplement No. A/59/10 (2004).

3. Second Report on Responsibility of International Organizations by Mr. Giorgio Gaja, Special Rapporteur, International Law Commission, Fifty-fifth Session, UN Doc. A/CN.4/541 (2004). 
4. Eighth Report on the Responsibility of International Organizations by Giorgio Gaja, Special Rapporteur, International Law Commission, Sixty-third Session, UN Doc. A/CN.4/640 (2011).

5. Draft Articles on the Responsibility of International Organizations, with Commentaries 2011, Report of the International Law Commission on the Work of Its Sixty-third Session, General Assembly Official Records, Sixty-sixth Session, Supplement No. 10 (A/66/10) (2011).

6. Model Agreement between the United Nations and Member States contributing personnel and equipment to United Nations peace-keeping operations, Report of the Secretary-general, UN Doc. A/46/185 (23 May 1991).

7. Contribution Agreement between the United Nations and Participating State Contributing Resources to the United Nations Peace-Keeping Operation, UN Doc. A/50/995 (9 July 1996).

8. Financing of the United Nations Protection Force, the United Nations Confidence Restoration Operation in Croatia, the United Nations Preventive Deployment Force and the United Nations Peace Forces Headquarters, Report of the Secretary-General, UN Doc. A/51/389, (20 September 1996).

9. Model Memorandum of Understanding between the United Nations and Participating State Contributing Resources to the United Nations Peacekeeping Operation, UN Doc. A/51/967 (27 August 1997).

10. Investigation by the Office of Internal Oversight Services into allegations of sexual exploitation and abuse in the United Nations Organization Mission in the Democratic Republic of the Congo, Report of the Secretary-Genral on the activities of the Office of International Oversight Services, UN Doc. A/59/661 (5 January 2005).

11. Sexual Violence and Exploitation: The Experience of Refugee Children in Liberia, Guinea and Sierra Leone, Report of Assessment Mission Carried out from 22 October to 30 November 2001, United Nations High Commissioner for Refugees, Save the Children - UK, January 2002.; https://www.parliament. uk/documents/commons-committees/international-development/2002-Report-of-sexual-exploitation-and-abuse-Save\%20the\%20 Children.pdf.

12. UN Peacekeeping Operations: Principles and Guidelines, UN Department of Peacekeeping Operations, 2008., http://www.refworld.org/docid/484559592.html.

13. United Nations Peacekeeping Missions Military Special Forces Manual, UN Department of Peacekeeping Operations, 2015., http://dag.un.org/bitstream/handle/-11176/89590/ United\%20Nations\%20 Peacekeeping\%20Missions\%20Special\%20Forces\%20Manual.pdf?sequence=1\&isAllowed=y.

14. Rezolucije Opće skupštine UN-a: UN Doc. A/RES/56/83 (2002), Resolution adopted by the General Assembly on 9 December 2011 (on the report of the Sixth Committee (A/66/473), Responsibility of International Organizations, General Assembly, Official Records, Sixty-sixth Session, 27 February 2012; A/RES/66/100 (2012).

15. Rezolucije Vijeća sigurnosti UN-a: UN Doc. S/RES/815 (1993); S/RES/819 (1993); S/RES/1244 (1999); S/RES/1386 (2001); S/RES/1546 (2004).

\section{OSTALI IZVORI}

1. Convention for the Protection of Human Rights and Fundamental Freedoms, usvojena u Rimu 4. studenog 1950., stupila na snagu 3. rujna 1953., UNTS, sv. 213, str. 220.

2. https://www.rt.com/news/186100-somalia-peacekeepers-rape-women/. 


\section{IN SEARCH OF THE MEANING OF THE EFFECTIVE CONTROL STANDARD IN PEACEKEEPING OPERATIONS UNDER THE AUSPICES OF THE UNITED NATIONS}

\section{Summary}

The subject of this paper is the analysis of the work done by the International Law Commission on the codification of international organizations responsibility for internationally wrongful acts, which resulted in the adoption of the Draft Articles on the Responsibility of International Organizations in 2011. The author focuses on Article 7 of the Draft, which prescribes prerequisites for the attribution of conduct in situations when the states place their bodies at the disposal of an international organization for peacekeeping operations. The analysis of relevant decisions of the European Court of Human Rights as well as of the courts of the Netherlands, Belgium and the United Kingdom points to the key problems that these courts faced while considering the attribution of violations of international law committed in peacekeeping operations - insufficient clarity of Article 7 regarding the attribution, different interpretation of the term 'placed at the disposal' of another international organization, lack of the definition of the 'effective control' standard, which is, according to the Draft prescribed as the criterion for the attribution of conduct, and consequently, the arbitrary application of control standards. The author warns that the lack of uniform jurisprudence as well as the mentioned shortcomings of the Draft Articles of the Responsibility of International Organizations cause legal uncertainty and reduce the possibilities for the victims of internationally wrongful acts to obtain adequate legal protection. In conclusion, the author proposes the application of the effective control standard as a well-established test in the context of attribution of conduct, explains the key elements of the content and the meaning of the standard, proposes guidelines for its correct application and points to the significance of the dual (multiple) attribution both to States and international organizations.

Keywords: $\quad$ responsibility of international organizations, the UN peacekeeping operations, effective control standard, dual (multiple) attribution of conduct

This work is licensed under a Creative Commons

Attribution-NonCommercial 4.0 International License.

* Rutvica Rusan Novokmet, PhD, Postdoc - lecturer at the Chair of International Law, Faculty of Law of the University of Zagreb, Ćirilometodska 4, 10000 Zagreb, Republika Hrvatska. E-mail address: rutvica.rusan@pravo.hr. ORCID: http://orcid.org/00000002-6235-1012. 